\title{
Blame it on the goats? Desertification in the Near East during the Holocene
}

Article

Accepted Version

Henry, D. O., Cordova, C. E., Portillo Ramirez, M., Albert, R.M., DeWitt, R. and Emery-Barbier, A. (2017) Blame it on the goats? Desertification in the Near East during the Holocene. The Holocene, 27 (5). pp. 625-637. ISSN 0959-6836 doi: https://doi.org/10.1177/0959683616670470 Available at https://centaur.reading.ac.uk/71058/

It is advisable to refer to the publisher's version if you intend to cite from the work. See Guidance on citing.

Published version at: http://dx.doi.org/10.1177/0959683616670470

To link to this article DOI: http://dx.doi.org/10.1177/0959683616670470

Publisher: SAGE

All outputs in CentAUR are protected by Intellectual Property Rights law, including copyright law. Copyright and IPR is retained by the creators or other copyright holders. Terms and conditions for use of this material are defined in the End User Agreement.

\section{www.reading.ac.uk/centaur}

\section{CentAUR}

Central Archive at the University of Reading 
Reading's research outputs online 


\title{
Blame it on the goats? Desertification in the Near East during the Holocene
}

Donald O Henry, ${ }^{1}$ Carlos E Cordova, ${ }^{2}$ Marta Portillo, ${ }^{3}$

Rosa-María Albert, ${ }^{4,5}$ Regina DeWitt ${ }^{6}$ and Aline Emery-Barbier ${ }^{7}$

1Department of Anthropology, Harwell Hall, The University of Tulsa, USA

2Department of Geography, Oklahoma State University, USA

3Department of Archaeology, University of Reading, UK

4 ERAAUB, Department of Prehistory, Ancient History and Archaeology, University of Barcelona, Spain

5Catalan Institution for Research and Advanced Studies (ICREA), Spain

6Department of Physics, East Carolina University, USA

7 Ethnologie Préhistorique, Maison de l'Archéologie et de l' Ethnologie, RenéGinouvès, CNRS, UMR 7041, Allée de l’Université, France

\begin{abstract}
The degree to which desertification during the Holocene resulted from climatic deterioration or alternatively from overgrazing has puzzled Quaternary scientists in many arid regions of the world. In the research reported upon here, a multi-disciplinary investigation of a 5-m deep, 11,000-year-old sediment column excavated in a dry lake bed in southern Jordan revealed an early interval in which proxies of plant cover and sheep/goat stocking rates co-varied directly with climatic cycles. Beginning $~ 5.6 \mathrm{kcal}$ BP, however, this pattern changed with fecal spherulite and phytolith densities failing to co-vary and with spherulites often greatly exceeding phytolith densities, which we suggest is indicative of overgrazing. Moreover, the lack of agreement between the high phytolith densities and other indicators of a desert landscape (i.e. geomorphic and palynologic) suggests that phytolith densities were inflated by fodder subsidies and as such are not entirely reflective of plant cover for this later interval. Given the coincidental emergence of overgrazing with archaeological evidence for a marked rise in regional population, emergence of widespread trade, and expansion of the Timnian pastoral complex during Chalcolithic-early Bronze times, we argue that desertification was a consequence of socio-economic factors (e.g. higher stocking rates) associated with a shift from a subsistence to a market economy. In addition, we contend that the signature lithic artifact variety (tabular scraper) that appeared in great abundance during
\end{abstract}


this period was directly tied to the emergent market economy and its secondary products (wool) in having been used to shear sheep. Moreover, in that these changes took place largely concurrent with local and regionally recognized evidence of a moist interval, we conclude that the mid- to late-Holocene desertification of the southern Levant was induced more by anthropogenic than climatic factors.

\section{Keywords}

Ayn Abū Nukhayla, Chalcolithic, desertification, Early Bronze, Jordan, overgrazing, phytolith, pollen, secondary products, spherulite, tabular scraper, Timnian Complex

\section{Introduction}

A vexing question facing Quaternary scientists is the degree to which desertification during the Holocene can be attributed to deteriorating climatic conditions associated with aridity or alternatively to overgrazing. Although other causes of desertification are entertained, climate change and herding are the factors most commonly identified as having brought about the transition from verdant land to desert. While this issue has been addressed globally (Geist and Lambin, 2004; Reynolds et al., 2003; Whiteford, 2002), the Near East has been a focus of research because of the region's inherently dry setting and concomitant vulnerability to the onset of arid conditions, coupled with the region's long history of pastoralism (Barker et al., 2007; Cordova, 2007; Falconer and Fall, 1995; Grigson, 1995; Hill, 2006; Kohler-Rollefson, 1988; Rosen, 2011b; Simmons, 2000). Most efforts to examine the question diachronically have focused on single lines of evidence from sedimentary, geomorphic, and paleobotanic research to trace the evolution of landscapes and on historic anecdotal studies of archaeofauna and paleo-demographic data to estimate the impact of herding. Moreover, low-resolution chronometries have limited the diachronic precision and regional integration of research findings. In the research reported upon here, situated in the hyper-arid setting of southern Jordan (Figure 1), we are able to integrate multiple lines of sedimentary, geomorphic, and paleobotanic data from a common sediment column in conjunction with information related to herding derived from archaeological evidence and fecal spherulites in a well-dated sequence covering the last 11,000 years. In tracing covariations within these datasets, we tease apart climate and overgrazing as proximate 
causes of landscape transformation and examine our findings in the context of the socioeconomic changes for the study area during the mid-Holocene.

The investigation represents part of a program of research associated with the excavation of the 9500-year-old, early Neolithic settlement of Ayn Abū Nukhayla (Henry, 2014b: 1-13; Henry and Beaver, 2014a). The overarching objective of the project focuses on the human behavioral ecology of the site's prehistoric occupants during this period of emergent agriculture.

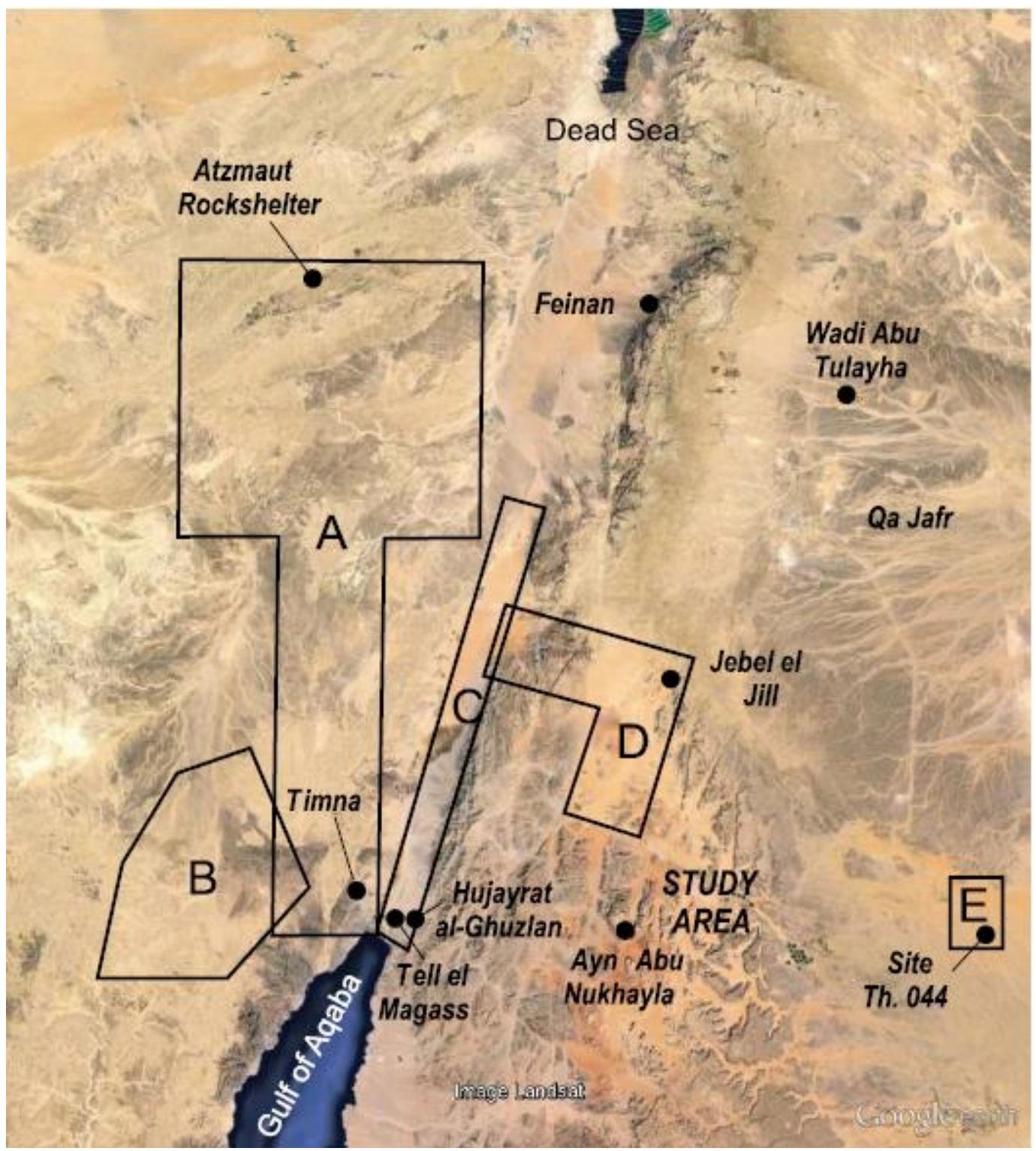

Figure 1. Map of the southern Levant showing the locations of the study area, sites, and archaeological survey areas mentioned in the text and prominent natural features of the region. The survey areas are those reported for (A) the Negev (Rosen, 2011b: 7), (B) east central Sinai (Eddy and Wendorf, 1999), (C) the southern Araba (Niemi and Smith, 1999), (D) the Hisma and adjacent Araba (Henry, 2006: 92-93; Henry et al., 2001), and (E) the al-Thulaythuwat area of SE Jordan (Abu-Azizeh, 2013). The approximate boundaries of the surveys are shown, but not all areas within the boundaries were surveyed. 
The site rests on a lobe of an alluvial fan within a deposit formed by the accumulation of aeolian sediments interlaced with the anthropogenic sedimentation of successive occupations that created a nascent tell (Figure 2). Erosion of the tell's surface has exposed the upper courses of some 150 stone-walled, mostly oval structures that are interconnected in a honeycomb pattern (Figures 3 and 4). The walls are associated with a rich scatter of chert artifacts, grinding stones, bones, and ash distributed over an area of approximately $1200 \mathrm{~m} 2$. With $<50 \mathrm{~mm}$ mean annual precipitation, the modern hyperarid setting of the area is one of the driest on earth with sparse desert vegetation and large expanses of drift sand.

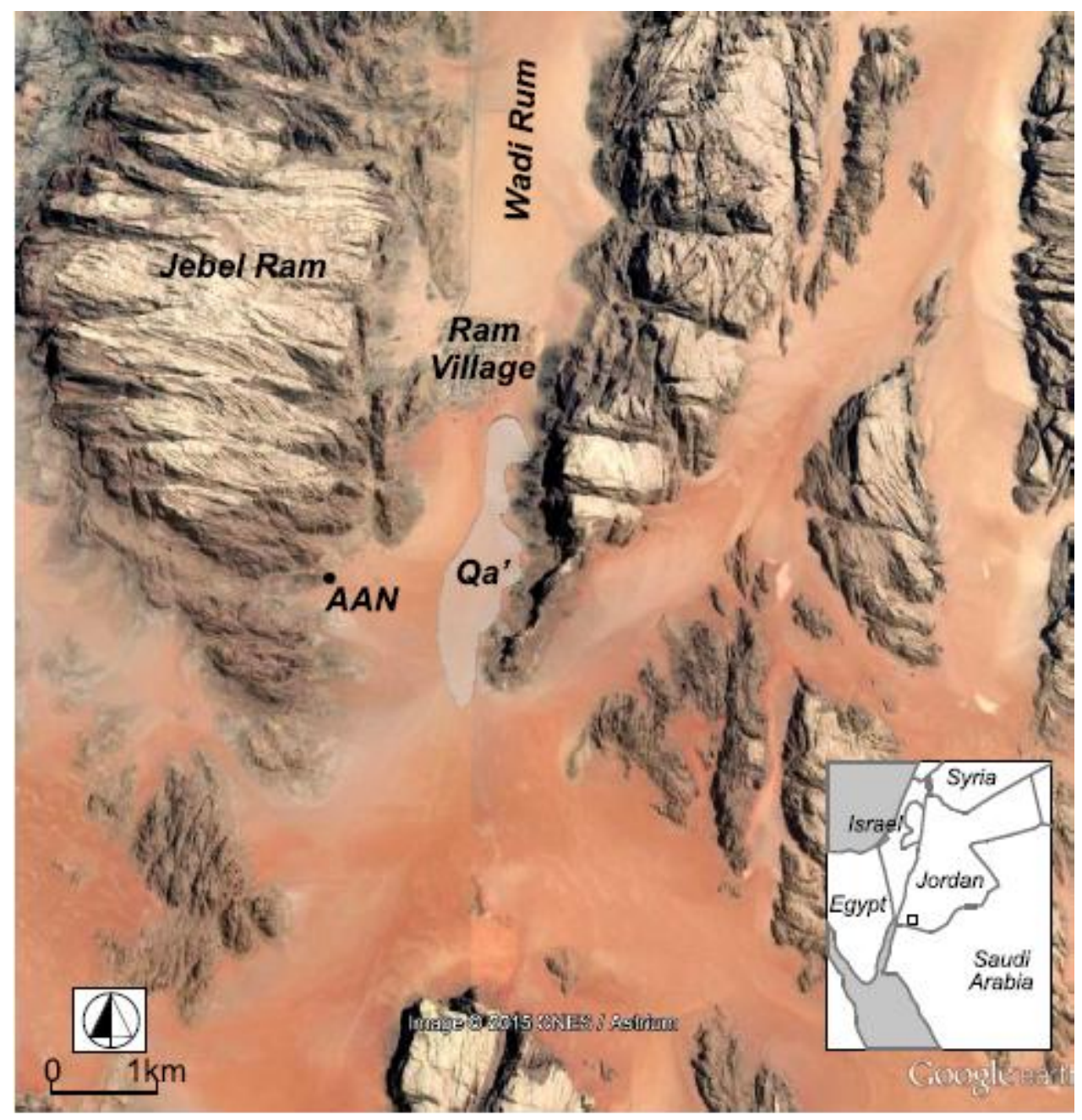

Figure 2. Satellite image of the landscape in the vicinity of the site of Ayn Abū Nukhayla showing the location of the site (AAN), the adjacent $q a$ ' and other prominent natural features. 
Radiocarbon assays from the site's deposit show the successive occupations to have encompassed about two centuries centered on $~ 9500$ years ago (Henry and Beaver, 2014b: 46-47; Henry and Nowell, 2007), thus placing the occupations late in the middle

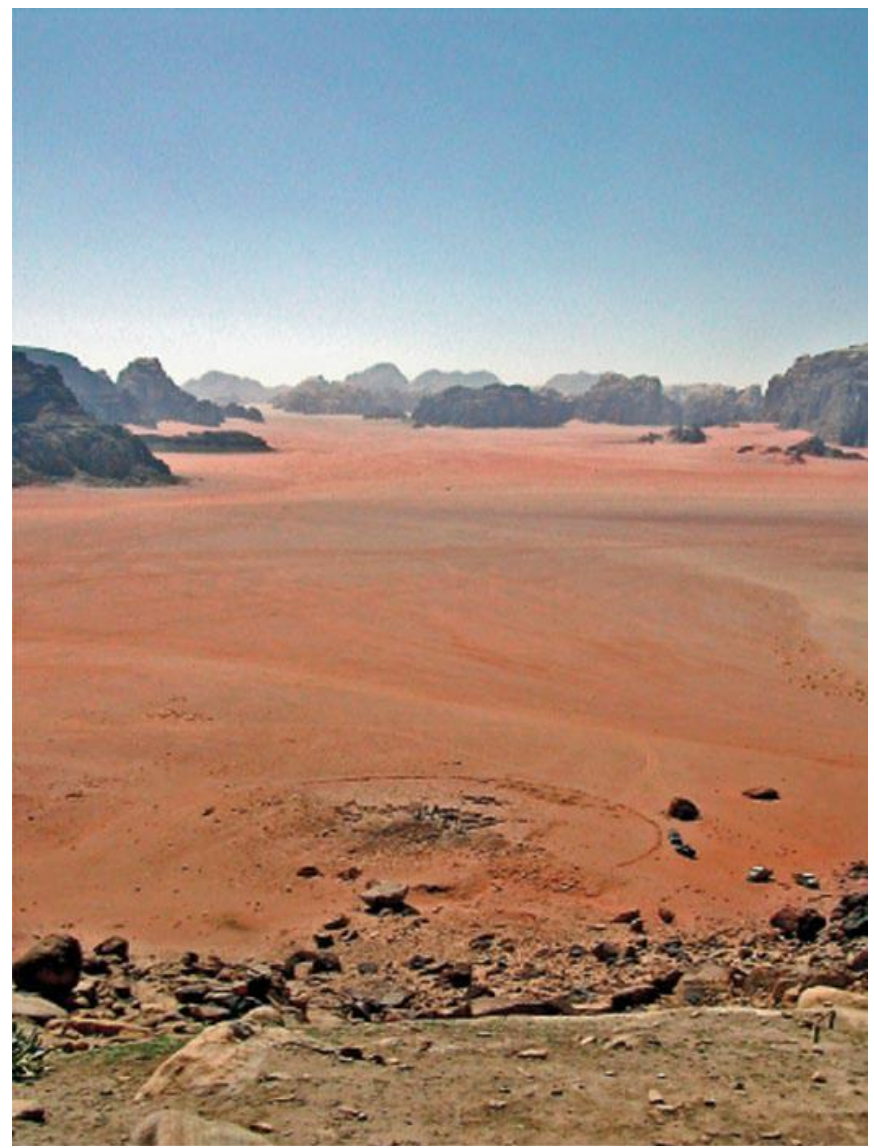

Figure 3. A view of the site of Ayn Abū Nukhayla looking to the SE across the Wadi Rum.

Pre-Pottery Neolithic B (PPNB) interval of the early Neolithic of the Levant (Kuijt, 2000; Simmons, 2007). This was a remarkable period of economic innovations, population growth and expansion, supra-regional social interaction, and an elaboration of ritual and ceremonial activities. Exploring the chain of causal relationships and triggering elements for these striking cultural changes has become a focus of research for Near Eastern prehistorians (Byrd, 2005; Goring-Morris and Belfer-Cohen, 2011; Kuijt and Goring-Morris, 2002). An important facet of these efforts is in understanding how early Neolithic groups were able to exploit the regionally dominant arid settings such as at Ayn Abū Nukhayla. A spring in the cliff above the site, from which it derives its name, was undoubtedly an attraction for prehistoric encampments, but the intensive early Neolithic settlement appears to have been mainly triggered by a brief moist pulse. 
The onset of moister conditions enabled the site's occupants to initiate cereal cultivation of the nearby mudflat $\left(q a^{\prime}\right)$ following seasonal ponding events from upland runoff. The multi-year investigation, however, traced a complex set of land-use strategies that involved a mixed economic package coupled with transhumance (Henry, 2014a: 317318). Herding of sheep and goats, cultivation of cereals, foraging, and trade provided a broad economic base. Moreover, the economic package was embedded in a transhumant strategy in which groups migrated from the site to better watered settings in the uplands of the Ma'an Plateau during the driest part of the year. This land-use strategy, involving a diversified economic base and seasonal movement to resources, acted to reduce risks and smooth economic short-falls in a harsh, variable environment.

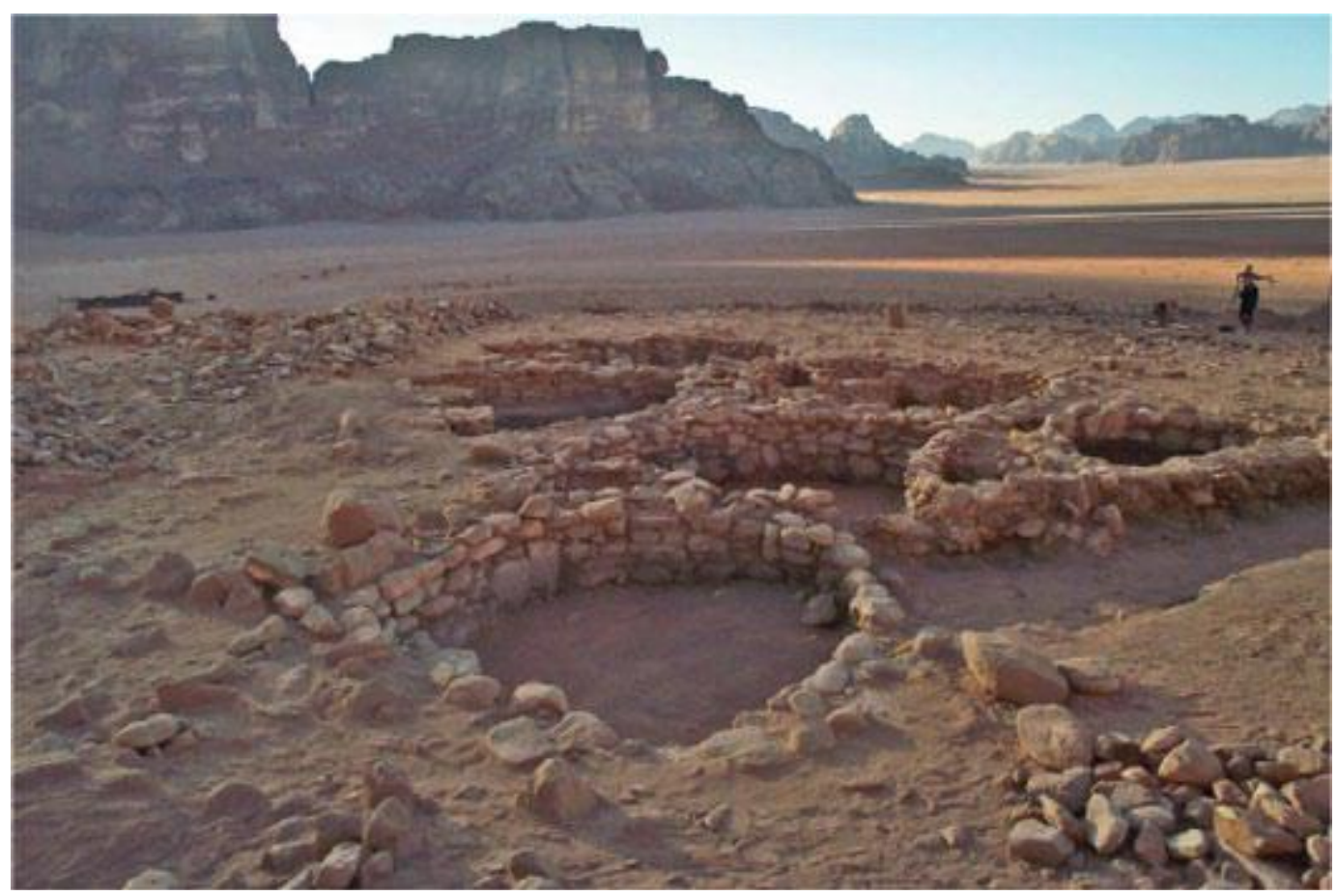

Figure 4. Image of the structures exposed by the excavation in Block I viewed to the SE.

Part of our research program also involved tracing the evolution of the local landscape and environment (Cordova et al., 2014: 26-27). In addressing these objectives, a deep stratigraphic sounding was dug into the former, small dry lake bed, Qa' Abū Nukhayla (Figure 5). As a sediment trap for the surrounding basin, the Qa' Abū Nukhayla furnished evidence that contributed to tracing the climatic, environmental, and economic successions of the area. The sounding, reaching a depth of $5 \mathrm{~m}$, yielded radiometric dates indicating that the deposit stretched back throughout the Holocene. The study of the $q a$ ' deposit provided a parallel line of research that allowed for the 
comparison of on-site anthropogenic evidence with off-site, largely naturally derived sources of information. This, in turn, enabled us not only to better understand how the early Neolithic inhabitants of the settlement exploited the natural environment of the area but also to explore the evolution of the local landscape and environment during the Holocene.
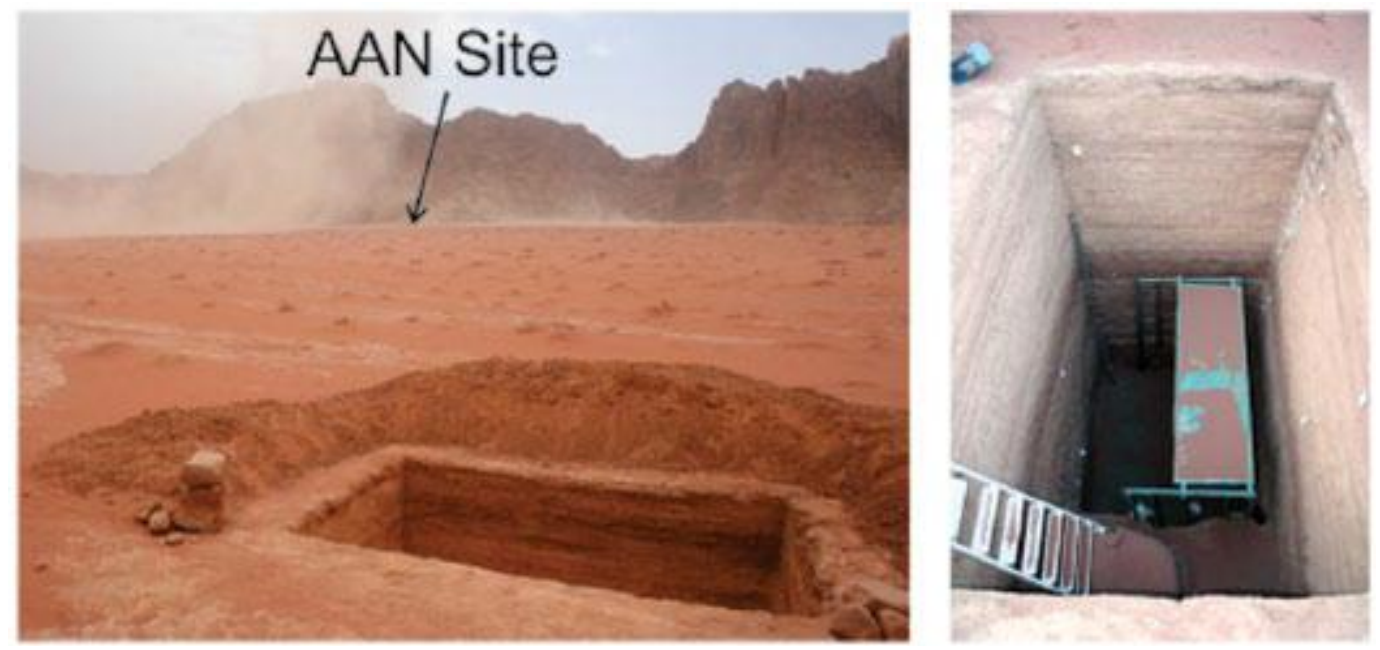

Figure 5. Images of $q a^{\prime}$ pit showing the site of Ayn Abū Nukhayla in background (left) and fine bedding of the dry lake deposit (right).

\section{Chronometry}

In order to compare the evidence recovered from excavation of the site with parallel data obtained from the $q a^{\prime}$ sounding and with that reported from broader regional studies, a relatively high-resolution chronometry was developed that incorporated radiocarbon and optically stimulated luminescence (OSL) techniques. Twelve conventional 14C assays of charcoal, broadly distributed stratigraphically and spatially across the site of Ayn Abū Nukhayla, yielded a mean age of $9504 \pm 32$ cal. BP and when evaluated together suggest the site was episodically occupied over a period of 180-240 years (Table 1; Henry and Beaver, 2014b; Henry and Nowell, 2007). The chronometry of the $q a^{\prime}$ 'sounding was based upon nine AMS 14C assays and eight OSL determinations (Table 1). The lowest OSL determination (sample Q-OSL-9) may have suffered contamination either from the reworking of sediments or from bleaching during collection. A plot of the depth/age points yielded a very high direct cubic regression value (0.958) that, in turn, allowed for using the resulting regression curve to determine depth/age chronometrics for the sedimentary units of the $q a^{\prime}$ deposit and associated evidence (Figure 6). 
An important concern when evaluating $14 \mathrm{C}$ dates in arid land contexts relates to the old wood problem in which wood may have been used as fuel centuries after the death of its source vegetation (Kuijt and Bar-Yosef, 1994: 233). Several factors, however, point to this as not being an issue in the research described here. Although the samples of charcoal used in the $14 \mathrm{C}$ assays were not identified to wood species, a study of large charred wood fragments $(N=1706)$ from across the excavation showed soft-woods (especially caper) as dominating the assemblage, whereas oak, the wood most likely to contribute to the problem, was very rare (McCorriston and Hayes, 2014: 140-142). Also, the relatively tight clustering of dates from the excavation is inconsistent with an old wood bias, except in the unlikely situation that all 12 assays from different spatial and stratigraphic contexts were derived from old wood. Finally, the age-depth curve developed for the $q a^{\prime}$ ' deposit shows strong correspondence between the $14 \mathrm{C}$ and the OSL assays, the latter not being subject to the old wood problem.

\begin{tabular}{llcrr}
\hline Method & Lab \# & Depth & Cal. BP & Sigma \\
\hline I4C AMS & A-I2279 & 65 & 1564 & 40 \\
OSL & Q-OSL-I & 70 & 2465 & 530 \\
I4C AMS & A-I2276 & 75 & 1757 & 45 \\
OSL & Q-OSL-2 & 110 & 3385 & 870 \\
I4C AMS & A-I2277 & 135 & 4580 & 45 \\
OSL & Q-OSL-3 & 150 & 5425 & 320 \\
I4C AMS & A-I228I & 165 & 5588 & 183 \\
I4C AMS & A-I2280 & 180 & 5743 & 50 \\
I4C AMS & A-I2278 & 200 & 5700 & 50 \\
OSL & Q-OSL-4 & 220 & 5595 & 350 \\
I4C AMS & Beta-I34455 & 238 & 7885 & 50 \\
I4C AMS & AA649I5 & 265 & 7934 & 46 \\
OSL & Q-OSL-5 & 310 & 7595 & 470 \\
OSL & Q-OSL-6 & 350 & 8755 & 550 \\
I4C AMS & AA649I6 & 354 & 9750 & 48 \\
OSL & Q-OSL-7 & 390 & 10,165 & 770 \\
OSL & Q-OSL-8 & 470 & 10,593 & 800 \\
OSL & Q-OSL-9 & 500 & $>9109$ & 1255 \\
\hline
\end{tabular}

Table 1. The 14C AMS and OSL dates (cal. BP, both 1-sigma standard error) for the $q a$ ' sediment column. The $14 \mathrm{C}$ dates were calibrated using the CalPal program (Weninger et al. 2007). OSL: optically stimulated luminescence. 


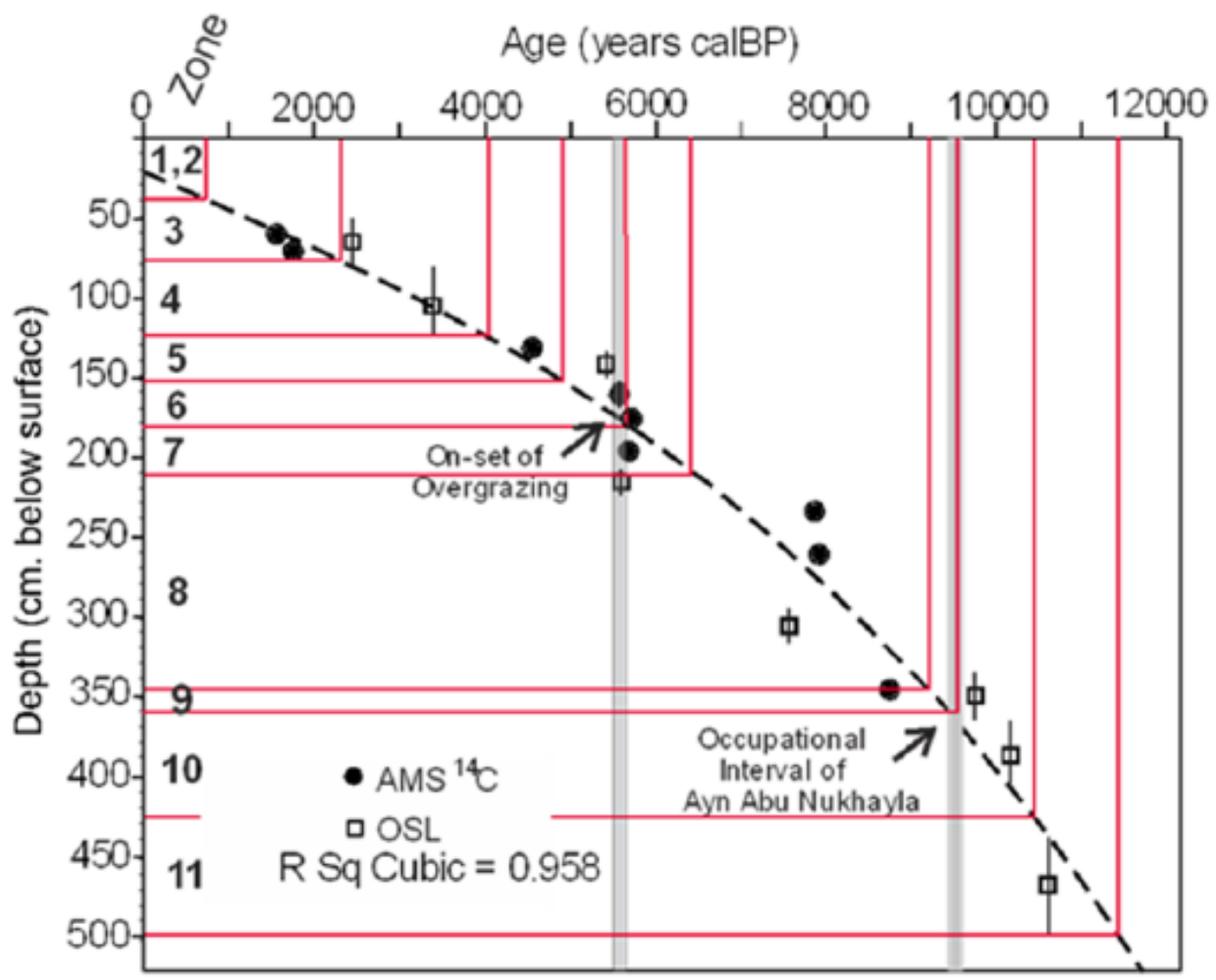

Figure 6. A depth to age plot showing the distributions of $14 \mathrm{C}$ and OSL dates (see Table 1) and a regression curve showing a polynomial fit $(\mathrm{R} \mathrm{Sq} \mathrm{Cubic}=0.958)$ to all point dates. Zones $1-11$ are also delineated. The standard error is shown for OSL determinations as a vertical bar; sigmas for 14C dates are too small for depiction. The $14 \mathrm{C}$ dates were calibrated using the CalPal program (Weninger et al., 2007).

\section{Stratigraphic zones: Sedimentary and paleobotanic evidence}

The 5-m deep sequence of the $q a$ ' deposit was divided into 11 stratigraphic zones based on sedimentological and pedostratigraphic characteristics and changes in the modes of sedimentation (Cordova et al., 2014). Stratigraphic correlation of the 11 zones with phytolith, pollen, starch, diatom and dung spherulite evidence, in turn, revealed corresponding biotic settings and economic activities in the local environment (Figure 7). This involved the analyses of 35 sediment samples split into sub-samples for specific studies: sedimentological (particle size, organic carbon (OC), magnetic susceptibility (MS) and microscopic charcoal (MC)), phytoliths, spherulites, pollen, and starches.

Zones 11-9 (>11,000 to $9200 \mathrm{cal}$. BP), at the base of the sequence, were principally formed of alluvial deposits of coarse sand (Zone 11) and finer and medium sand (Zone $10, \sim 10,500$ to $\sim 9500 \mathrm{cal}$. BP), ending with the deposition of a quasi-lacustrine, $q a$ ' type deposit (Zone 9, 9200 cal. BP) that suggests ponding. Overall, the sequence from Zone 11 to 9 indicates an increasingly moist environment. OC, MS, and MC all exhibit relatively high values for the interval, especially for that segment of the deposit that was laid down synchronous with the occupation of Ayn Abū Nukhayla. The high values for 
organics during the interval are consistent with the inferred greater available moisture and high plant biomass for the area. Similarly, organic-rich silts would have contributed to the high magnetic properties and the relatively dense vegetation cover would have been susceptible to natural and anthropogenic brush fires that would have contributed to the high MC values. The MC in the deposit is also likely to have come from the numerous hearths in the nearby site and from fires used in field settings by the residents of the settlement while they farmed the $q a$ '.

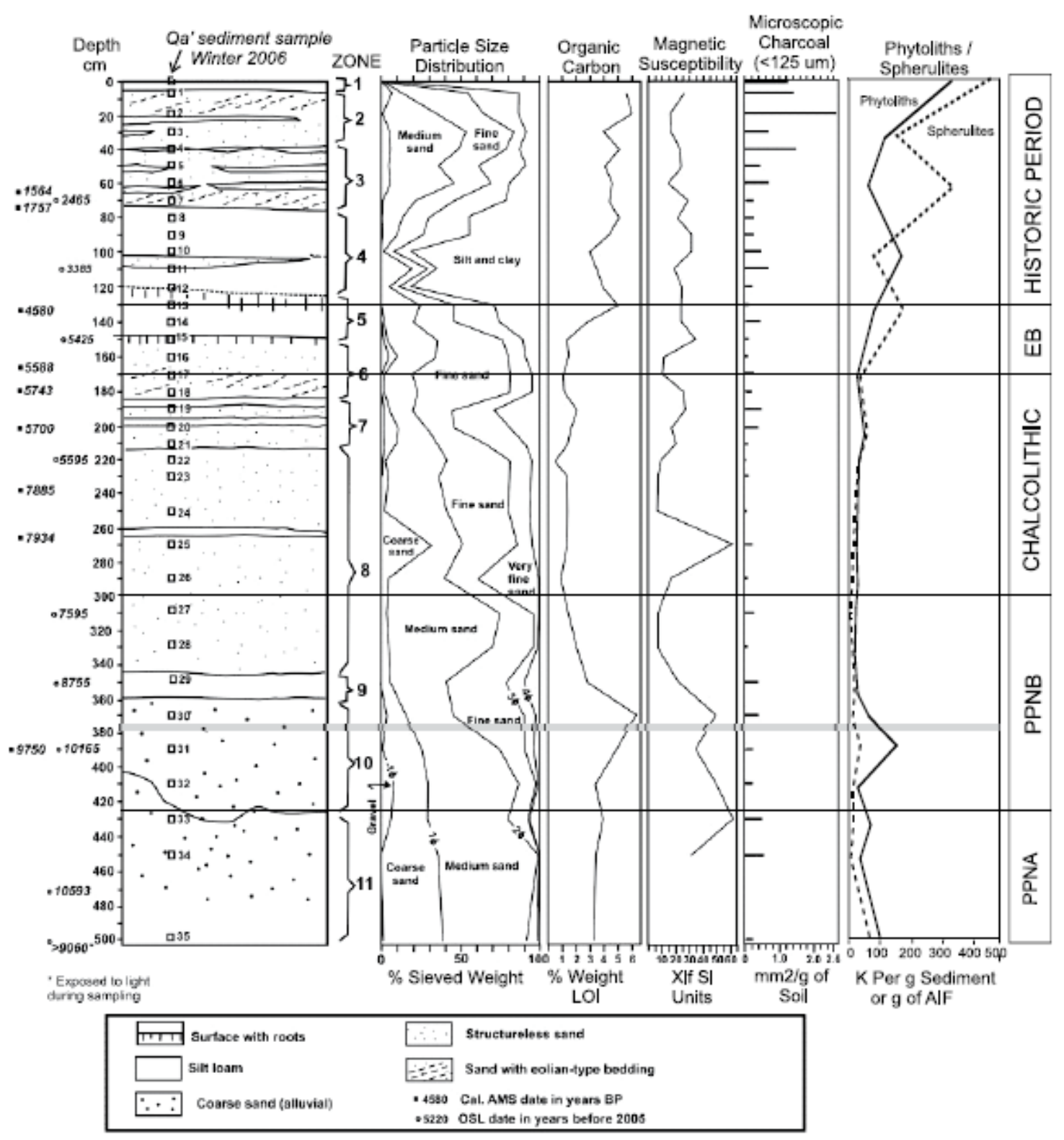

Figure 7. Diagram of the sediment column excavated in the Qa' Abū Nukhayla showing the chronostratigraphic integration of the various data-sets discussed in the text. 
Analyses of phytolith, pollen, and starch evidence also suggest progressively moister conditions for the interval. The frequency of phytoliths varied considerably within the overall $q a^{\prime}$ sequence, occurring in low frequencies in most of the samples, but they were relatively abundant in this lowest interval, peaking near the top of Zone 10. The grass family (mostly from the C3 pooid subfamily of cool season grasses) dominated the phytolith record, followed by woody dicotyledonous phytoliths. Moderate frequencies of Chenopodiaceae pollen, an arid indicator, were recovered along with small quantities of arboreal pollen of Pinus (pine), Juniperus (juniper), Capparis (caper), and Quercus (oak). But floral indicators of a much more moist setting than that of today and pointing to the presence of perennial water were identified in the pollinic spectra (Figure 8). These included Concentricystes algae, Typha (cattail), Salix (willow), Tamarix (tamarisk), and Alnus (alder), which is no longer found in Jordan. This interval also displayed the highest level of phyto-diversity for the entire sequence with 51 taxa represented. Moreover, the presence of Cerealia type pollen, numerous well-preserved fossilized starch grains, and phytoliths morphometrically identified as most likely coming from wheat points to cereal cultivation in the vicinity of the $q a^{\prime}$ synchronous with the occupation of the site (Emery-Barbier, 2014; Portillo and Albert, 2014; Portillo et al., 2009).

Zone 8 ( 9200 to $\sim 6400$ cal. BP) was dominated by the sedimentation of medium, aeolian-derived sand, suggestive of a hyper-arid phase. This relatively long interval was briefly interrupted by the deposition of silt, possible in a $q a$ ' type environment, between samples 24 and 25. For the zone, OC, MS, and MC values are low, as would be expected for the very dry conditions, with an exception to an MS peak accompanying the brief $q a^{\prime}$ development at $\sim 260 \mathrm{~cm}$ depth.

The fluctuations noted in phytolith abundances may relate to preservation (i.e. higher dissolution rates around $30 \%$ in the poorest sample), aeolian dispersion, or animal fodder/dung (as indicated by the correlations of larger phytolith abundances along with spherulites as discussed later). The low plant cover expected under these hyper-arid conditions, however, would also have resulted in the lowest densities of phytoliths (24$38,000 / \mathrm{g}$ AIF) of those samples recorded in the $q a^{\prime}$ ' deposit. Only two sediment samples from the zone yielded pollen, which was limited to small quantities from pine and juniper that were likely blown in from the higher elevations of the Ma'an Plateau or the nearby Jebel Ram. 
Zone 7 ( 6400 to $\sim 5650$ cal. BP) represented a relatively short interval of cyclical sedimentation of aeolian sand and the formation of lacustrine ( $\left.q a^{\prime}\right)$ deposits, suggesting alternate periods of dryness and moisture. Although sporadic, the elevated moisture budget and expected increased biomass are reflected in the rise of OC, MS, and MC values.

Given these conditions, the inferred expansion in plant cover also is expressed in a rise in phytolith density relative to the previous zone, but still recorded at a relatively low level of 58,000/g AIF. This is especially noteworthy given that the phytoliths are mostly from dicotyledonous plants, which are minor phytolith producers. It is interesting to note here that monocots not only produce up to 20 times more phytoliths than dicot wood and bark and 16 times more than dicot leaves, they are also present as an exterior contamination on bark used as fuel (Albert and Weiner 2001; Albert et al., 2003; Tsartsidou et al., 2007). The pollen spectrum, apparently associated with ponding during a wet episode in the upper part of the zone, displayed Typha and Phragmites pollen along with algae spores. As in Zones 11-9, the recovery of Cerealia pollen points to the cultivation of the $q a^{\prime}$ during moist intervals. The observation of an exceptional quantity of microcharcoals in the pollen analysis also suggests the more frequent occurrence of natural and anthropogenic fires.

Zone 6 ( 5650 to $\sim 4900$ cal. BP) was composed mainly of fine, aeolian sand that clearly displayed bedding structures. This sequence ends with a relatively wet and geomorphically stable period, which is characterized by the formation of an incipient A soil horizon. The floral response to the onset of drier conditions, followed by greater available moisture, is seen in the initial drop and subsequent slight rise in OC and MS values. MC values remained low throughout the interval and showed only slight fluctuation. The sediment sample from this zone for paleobotanic analysis yielded a low density of phytoliths and a sterile pollen sample.

Zone 5 ( $\sim 4900$ to $\sim 4050$ cal. BP) encompassed a relatively brief phase of silt accumulation typical of a $q a^{\prime}$ deposit. In contrast with the dry conditions accompanying accumulations of sand, silt deposition occurs when aeolian silt settles down by rain in the basin. Therefore, this phase suggests the prevalence of relatively moist conditions. Also, an incipient soil A horizon, formed on top of this deposit, points to increased moisture levels and greater sediment stability. 
A marked rise in OC accompanies the soil formation at the top of the zone, while MS and MC levels display modest fluctuations. Phytolith density also increases sharply to a relatively high level $(97,000 / \mathrm{g})$. Pollen grains were not well preserved with $26.4 \%$ being unidentifiable, while the percentage of unidentifiable pollen grains is $4.1 \%$ in Zone 2, $0.65 \%$ in Zone 3, $19.7 \%$ in Zone 4, and $7.4 \%$ in Zone 11 . Arboreal pollen was absent. However, despite being highly resistant to deterioration, Chenopodiaceae pollen represented only $18.7 \%$ of the spectrum. This relatively low representation of a clear floral signature of aridity is also consistent with Zone 5 as representative of a moist interval.

Zone 4 ( 4050 to 2300 cal. BP) consisted mostly of $q a^{\prime}$ silt deposition interrupted by a short phase of aeolian sand in the middle of the zone. Both OC and MC levels remain similar to those of Zone 5, but fluctuate with the incursion of aeolian sand in the middle. In general, this zone represents moist conditions, but not as prominent as during the deposition of Zone 5. Phytoliths sampled from the lower part of the zone occur in high density and the pollen spectrum contains several representatives of waterside flora in addition to desert vegetation dominated by moderate frequencies of Chenopodiaceae pollen.

Zones 3-1 ( 2300 cal. BP to present) trace an interval of cyclical $q a^{\prime}$ silt deposition with interbedded aeolian sand associated with fluctuating conditions between moist and dry, typical of what has been witnessed in recent decades. Values for OC and MS register moderate-high ranges, somewhat unusual for an arid setting in that the abundance of organics in sediments of arid environments is typically low. The values of OC and MS peak near the top of the interval in recent times in conjunction with high concentrations of $\mathrm{MC}$, an indicator of the burning of large plant biomass or the intentional burning of overgrown floors of structures and animal pens and as fuel for fires in anthropogenic contexts.

The microbotanic evidence for the interval shows phytoliths to have been relatively abundant with the highest value of the entire sequence in sample 0 at the top of the interval. This may in part be because of the better preservation conditions in upper levels and plant composition dominated by grasses, as these produce phytoliths in larger amounts. Pollen, however, is dominated by the high representation of Chenopodiaceae and Artemisia, signatures of an arid environment. Morus (mulberry) and Olea (olive) appear as new cultivars introduced to the area during the interval. 
The apparent paradox of an abundance of phytoliths, seemingly indicative of high plant biomass and ground cover, in association with a dominance of desert plants with limited taxonomic diversity, may be explained by the use of agricultural by-products (i.e. chaff derived from threshing of cereals) for the foddering of herd animals. Modern rangeland studies for the region and locally within the study area estimate that natural pasture provides only about $30 \%$ of the forage for herd animals, with the rest coming from cultivated crops, mainly in the form of straw from cereal grasses (Al-Jaloudy, 2001). With sheep and goats requiring about $1.35 \mathrm{~kg}$ dry matter per animal daily, some $1 \mathrm{~kg}$ of fodder would be needed to sustain an animal. Given this, several metric tons of fodder are likely to have been introduced to the study area annually with a wide dispersal throughout the drainage basin. This grass subsidy would have contributed a significant quantity of phytoliths to the uppermost part of the $q a$ ' deposit derived primarily form dung deposition as evidenced by the associated spherulite concentrations.

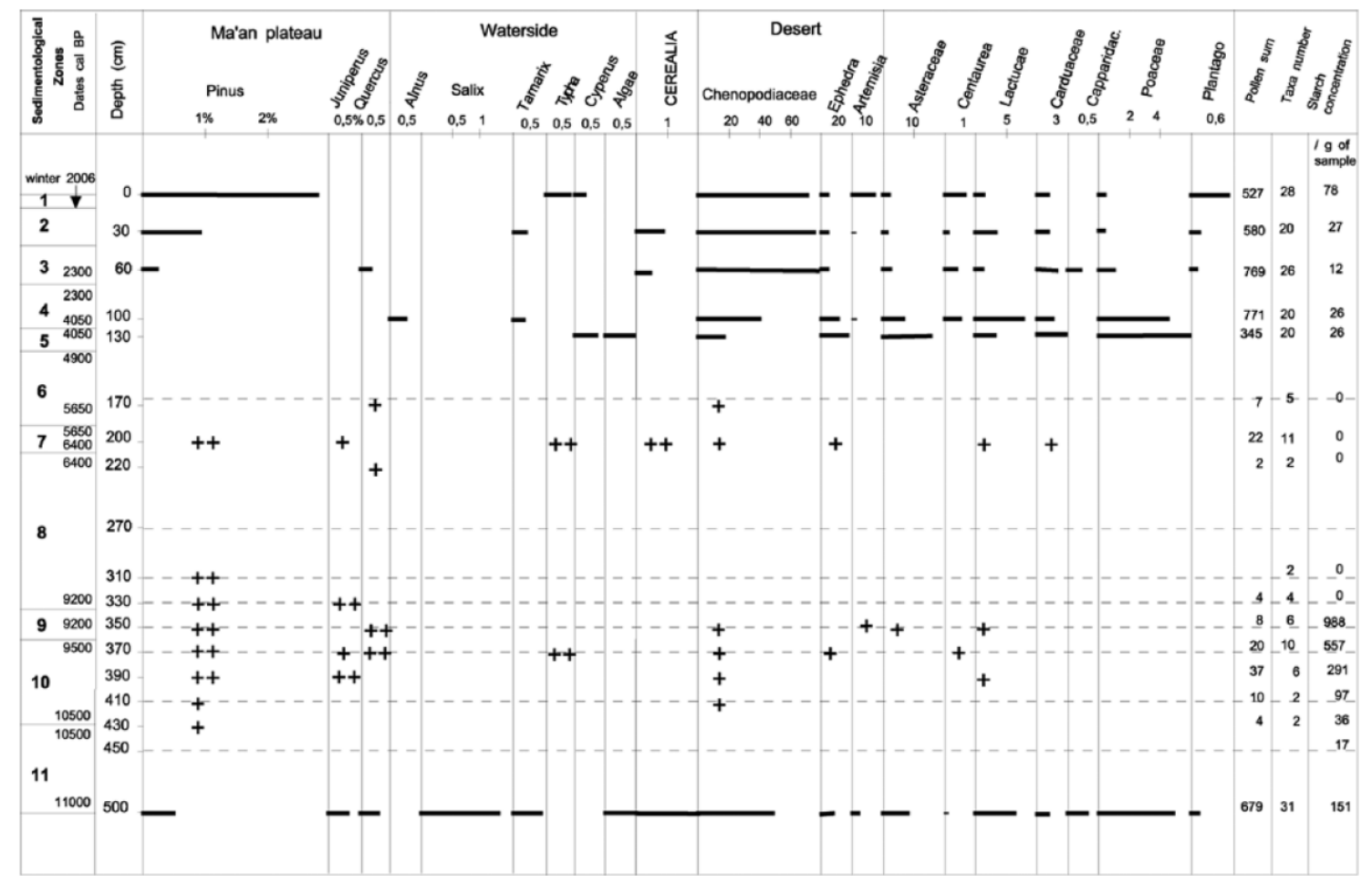

Figure 8. Pollen diagram developed from the sediment column of the $q a$ '.

\section{Herding, stocking rates and overgrazing}

Traditionally, herding has been thought to have been introduced to the arid zone of the southern Levant relatively late in the Neolithic, after about $\sim 8900$ years ago, during the 
late Neolithic (Garrard et al., 1996: 221) and thus considerably later than in the northern Levant and Anatolia (Baird, 2014; Stiner et al., 2014). However, the recent recovery of evidence from Ayn Abū Nukhayla, and the nearly synchronously occupied site of Wadi Abu Tulayha (Fujii, 2010) situated in Jordan's eastern desert, shows that Desert Neolithic groups herded sheep and goats as early as 9500 years ago. At Ayn Abū Nukhayla, the herding of domesticated sheep and goats is confirmed by a wide array of data including the very high proportionate representation $(93 \%)$ of ovicaprines within the macrofaunal assemblage; the morphometrics of humerus, astragalus, and metacarpal elements and horn core morphology; the location of the site outside the natural biogeographic ranges of ovicaprines; the age-sex profiles of the ovicaprines; and the concentrations of fecal spherulites recovered from housefloor deposits (Albert and Henry, 2004; Dean, 2014; Henry, 2014a: 320-322; Henry et al., 2014; Portillo and Albert, 2014; Portillo et al., 2009).

Fecal spherulites, calcium carbonate crystals, are formed in the intestines of certain animals, especially ruminants, and as such provide a signature of dung (Brochier et al., 1992; Canti, 1997, 1998, 1999). The identification of concentrations of fecal spherulites in two of the excavated structures in the site not only provided additional evidence for herding but also showed that some of the pithouses had dual uses as living quarters and also as animal enclosures - most likely lambing pens (Albert and Henry, 2004; Portillo and Albert, 2014; Portillo et al., 2009). This is, in fact, a common practice for the Bedouin tent-groups living in the area today (Albert and Henry, 2004; Portillo and Albert, 2014; Simms, 1988; Simms and Russell, 1997). In the off-site context of the qa' deposit, fecal spherulites were also identified in varying densities (Figure 7). In the lower portion of the sequence, spherulites display relatively low values $(<75 / \mathrm{g})$, but beginning in upper Zone 6 they rise sharply to ultimately reach very high densities of 471,000/g in Zone 1. Although factors related to preservation, in part, may account for the variability in spherulite densities, the most direct interpretation is that their abundance is principally determined by the number of animals pastured and the duration of their pasturage in a defined area, that is, the stocking rate.

Spherulite preservation in sediments is because of several factors, but it is commonly related to diagenesis, as they are particularly susceptible to dissolution in acidic $\mathrm{pH}$ burial conditions when organic matter degrades (Canti, 1999). Shahack-Gross et al. (2003) pointed out that spherulite high solubility is related to their mineralogical 
composition, which is a relatively unstable carbonate form. These microfossils may even dissolve in neutral $\mathrm{pH}$ conditions (i.e. by rain water). While different sedimentary conditions, possibly related to precipitation values, may have affected their preservation in the $q a$ ' sequence, the higher presence of these calcitic microremains associated with the increase in phytolith abundance suggests that their fluctuating differences principally result from the influx of fecal material. The reasoning here is that the varying abundance of spherulites in the sediment column does not show an inverse relationship to evidence for moister conditions as expressed in sedimentary, phytolith, and pollen data.

Of significance here is that the relative abundance of fecal spherulites, phytoliths, and pollen in the $q a$ ' sequence offers a means of tracing the diachronic changes of stocking rates and the vegetational richness of the area. For the lower portion of the sequence (Zone 11-Lower Zone 6), spherulite densities register slightly below or nearly equal to those of phytoliths, but in the upper part of the sequence (Upper Zone 6-Zone 1), the densities of spherulites are typically greater than those of phytoliths, often substantially so. Read directly, this suggests that stocking rates were relatively low for the early part of the sequence and varied directly with the vegetational biomass as would be expected if herds were principally supported by pasturage. But beginning after 5600 years ago, not only did stocking rates apparently rise, but they often failed to co-vary with fluctuations in plant cover and sometimes appear to have greatly exceeded the vegetational biomass such as in Upper Zone 6 and Zones 5, 3, and 1. This is thought to trace the onset of overgrazing in the region, but we also need to consider the potential bias that fodder, used to supplementnatural forage, would have had on the overall abundance of phytoliths.

In regard to the use of fodder, Zone 1 is particularly revealing in that it represents samples recovered from sediments deposited in a ponding event on the $q a^{\prime}$ over the winter of 2006, a temporal interval for which we have high-resolution, modern base-line data for both stocking rates and vegetational cover. Local (Henry, 2014a) and regional (Al-Jaloudy, 2001; Batello, 2011; Kochy et al., 2008) rangeland studies report annual stocking rates at 0.7-2.3 animals/ha with the area included within Ayn Abū Nukhayla's site exploitation territory and represented in the $q a$ ' sediments falling near the lower end of this range (Henry, 2014a: 336-338). The rangeland of the region is also noted to be 
extensively overgrazed (Al-Jaloudy, 2001; Koch et al., 2009; Kochy et al., 2008), up to three times over carrying capacity (Batello, 2011).

While the very high spherulite density $(471,000 / \mathrm{g})$ of Zone 1 is to be expected given the human settlement intensity of the nearby Ram Village and attendant numbers of herd animals (Wadi Rum, 2011), the very high phytolith density $(350,000 / \mathrm{g})$ is unexpected for such a hyper-arid setting. The sparse vegetation density of the area was confirmed in a botanic study undertaken in 2007 that recorded an average of 723 plants $/ \mathrm{km} 2$ and only a 30\% plant cover (Al Zaidaneen, 2007). This lack of direct agreement between vegetation density and phytolith abundance is likely explained by the introduction of phytoliths into the environment via cereal fodder for herd animals. In the region, natural forage for sheep/goats accounts for only about $30 \%$ of their dry mass consumption (AlJaloudy, 2001; Batello, 2011), the rest coming from fodder. In the hyper-arid setting of the Wadi Rum, natural forage likely furnishes even less support and tons of fodder are dispersed annually across the landscape in open feeding areas and in dung. Introduction of phytoliths in fodder is also supported by the extraordinary abundance of grass phytoliths in the Zone 1 sample, accounting for about $65 \%$ of the spectrum (Figure 7). While we recognize that the data collected in the modern rangeland studies of Wadi Rum and other regional locations should not be used as direct analogues relative to prehistoric land-use practices, they are relevant to better understanding the varying abundances of phytoliths and spherulites. The ability to transport water, livestock, and fodder by modern Bedouin groups has greatly altered traditional practices, especially relative to stocking rates and the degree of overgrazing. However, the modern baseline evidence from (1) the rangeland studies, (2) the botanic survey, and (3) the 2005/2006 sedimentary layer of the $q a^{\prime}$ column contributes to better understanding the relationships between ground cover, stocking rates, supplemental fodder, and phytolith and spherulites densities, and this, in turn, allows for the reconstruction of earlier Holocene land-use patterns.

\section{Discussion}

While spherulite, phytolith, and pollen densities within the sedimentary succession of the study area appear to provide reasonable proxies for tracing diachronic changes in stocking rates and vegetational biomass, the degree to which the phytoliths were introduced as natural plant cover as opposed to animal fodder represents an important 
consideration. In the upper part of the $q a^{\prime}$ sequence (upper Zone 6-Zone 1), both phytolith and spherulite densities increase markedly over those recovered from Zones 9 through lower Zone 6. In observing this, we suggest that phytolith densities for upper Zone 6 through Zone 1 should be in the 20-35,000/g AIF range as recorded in the similarly arid environments of Zone 9 through lower Zone 6 and that the very high densities (63-350,000/g AIF) of phytoliths in upper Zone 6 through Zone 1 are not principally from natural vegetation, but from fodder (especially straw) that was used in supplementing natural pasturage. Use of straw for animal fodder during this interval finds further support in a sharp rise in the proportion of grass phytoliths, increasing from about $26 \%$ in lower Zone 6 to over $50 \%$ in Zone 5 (Portillo and Albert, 2014: 127, Figure 9.2).

\section{The beginnings of overgrazing: Botanic and zooarchaeologic signatures}

An examination of the pollen diagram of the upper part of the $q a^{\prime}$ deposit (EmeryBarbier, 2014: 110-111, Figure 8.2; Figure 8) shows an increased abundance of pollen from ruderal weeds for this interval, especially those of the Asteraceae family including thistles (e.g. Carduaceae, Centaurea), that are known to be grazing-resistant, nonpalatable plants and as such serve as markers of intensive herding (Langgut et al., 2014; Zohary, 1973). Pollen of common plantain, Plantago lanceolata, a plant that benefits from grazing pressure via the nitrates introduced from livestock dung (Cordova, 2007: 114), also appears in this interval, peaking sharply in Zone 1. In light of these data, the marked elevation in fecal spherulite densities beginning inupper Zone 6, after 5600 years ago, suggests that unlike the earlier part of the sequence (Zone 11-lower Zone 6), the study area is likely to have experienced very high stocking rates and the onset of overgrazing at this time. Although excessive stocking rates and overgrazing are widely recognized for the region in modern times (Al-Jaloudy, 2001; Batello, 2011; Koch et al., 2009; Kochy et al., 2008; Lancaster and Lancaster, 1991), the historic beginnings of the practice are poorly understood. Some researchers have suggested that overgrazing was partially responsible for changes in settlement distribution as early as the PPNB, resulting in a reduction in plant cover in core regions and increased use of desert areas accompanied by the emergence of sheep/goat pastoralism (Falconer and Fall, 1995; Grigson, 1995; Hill, 2006; Kohler-Rollefson, 1988; Simmons, 2000: 220; Tchernov and Horwitz, 1990). Rosen (2011b), however, argues that an extrapolation of modern 
processes and conditions into the deep past is unwarranted and that the linkage between overgrazing and desertification in the nearby Negev is a modern phenomenon. In their geomorphic study in the Negev highlands, Avni et al. (2006: 197-198) also failed to find any archaeological evidence of overgrazing and instead viewed Holocene desertification as resulting from an arid climate with occasional high-intensity rainfall that induced erosion with any anthropogenic environmental impact superimposed on natural trends. Relative to Neolithic pastoralism, Rosen (2011b: 2-3) suggests that population densities were too low and herd sizes too small to have induced overgrazing and that there is a paucity of evidence of pens or corrals for controlling herd animals. While early Neolithic sites are uncommon in the arid zone of the Levant, there is good evidence for the penning of herd animals at Ayn Abū Nukhayla (Albert and Henry, 2004; Portillo and Albert, 2014; Portillo et al., 2009) and Wadi Abu Talayha (Fujii, 2010) as early as 9500 years ago. But herd sizes developed from independent estimates of stocking rates for Ayn Abū Nukhayla's site catchment are about 60 animals per household (Henry, 2014a:338), representing less than 20\% of the animals per household reported today (Al-Jaloudy, 2001; Blench, 1999; Lancaster and Lancaster, 1991). Although herding of sheep and goats was clearly part of their economic package, Desert Neolithic groups appear to have maintained stocking rates below the carrying capacity of pasturage to the degree that overgrazing was not induced. The relative densities of fecal spherulites and phytoliths shown in the lower part of the $q a^{\prime}$ diagram (Figure 7) are consistent with stocking rates being held below carrying capacity for the interval as reflected in spherulite densities always falling lower and fluctuating in concert with those of phytoliths.

Beginning shortly after $\sim 5.6 \mathrm{kcal} \mathrm{BP}$ near the beginning of early Bronze I, however, this pattern changed in the $q a^{\prime}$ diagram with fecal spherulite densities rising rapidly and exceeding those of phytoliths for the first time. We interpret this as a signature for the onset of overgrazing and the beginning of anthropogenic/zoogenic desertification of the study area and likely beyond. Regionally, faunal studies defining the diachronic distributions of herd animals (Grigson, 1995; Tchernov and Horwitz, 1990) and a palynological investigation of a thick dung deposit at Atzmaut rockshelter (Babenko et al., 2007) in the Negev provide important complementary data for tracing Holocene pastoralism in the Levantine arid zone. 
In following the approach developed by Tchernov and Horwitz (1990) for tracing herd sizes and composition, Grigson (1995) examined the relative contributions in meat yield of domestic animals recovered from late Neolithic through Iron Age sites situated in three areas of different carrying capacity of rangeland in the southern Levant. For the desert margin area, which concerns us here, she found sheep/goat and cattle to be relatively evenly represented, each providing about $50 \%$ of meat from the late Neolithic through the Chalcolithic, but beginning with the early Bronze the sheep/goat contribution rose sharply to almost $70 \%$. In agreeing with the earlier interpretation of Tchernov and Horwitz (1990), she attributed this emphasis on sheep/goat production to the transition from a subsistence to a market economy (Grigson, 1995: 251). She went on to propose that in this context, sheep would have been raised largely for their secondary products (milk and wool) which would have been traded to the emergent population centers of the early Bronze age. She supported her observation by noting the progressive rise in the representation of sheep from late Neolithic to early Bronze times (Grigson, 1995: 252-253).

Research at the livestock stabling site of Atzmaut rockshelter produced a pollen diagram from a thick dung deposit laid down in the shelter over the last 5800 years (Babenko et al., 2007). Given that the site is also located in the arid zone of central Negev Desert about $130 \mathrm{~km} \mathrm{NW}$ of the study area, the diagram provides an important data-set for comparison with the upper part of the $q a^{\prime}$ deposit (Upper Zones 6-1). In addressing the effect of livestock grazing on vegetation, Babenko et al. (2007) point to the relative abundance of Plantago species pollen as an expression of the grazing load. As noted earlier, Plantago benefits from nitrate fertilization by livestock, and as such, the relative abundance of Plantago pollen provides a proxy for stocking rates (Baruch, 1990; Cordova, 2007). In the Atzmaut rockshelter diagram, Plantago pollen frequencies display two striking peaks, one somewhat before 5000 years ago and another in recent times (Babenko et al., 2007: 393, Figure 5). The authors point out that the first peak coincides with the increased density of archaeological sites during the early Bronze as defined in a regional study by Rosen (2011a). While a comparison of the Atzmaut diagram with corresponding data from Qa' Abū Nukhayla is consistent in denoting several proxies that trace a marked rise in stocking rates, Plantago pollen is noticeably absent from the beginning of the upper part of the $q a^{\prime}$ ' diagram (Emery-Barbier, 2014: 110-111, Figure 8.2). Here, it is important to recognize, however, that the inherently 
drier conditions and poorer plant cover in the Wadi Rum would have resulted in a carrying capacity of the rangeland which would have been much less than that of the central Negev. Given this, stocking rates may have reached the threshold levels to induce overgrazing of the study area before sufficient nitrate concentrations had developed to the degree necessary for stimulating the expansion of Plantago as seen in the Negev. This notion finds support in the co-variation seen between fecal spherulite densities and Plantago pollen frequencies in the upper part of the qa' diagram.

\section{An ultimate cause?}

While the proximate cause of desertification of the southern Levant beginning 5600 years ago appears to have been from overgrazing, what was the ultimate cause? Could climatic deterioration have been the ultimate cause with excessively high stocking rates simply accelerating the tipping point for the onset of landscape transformation or were other forces at play? A climatic explanation appears less compelling than one associated with a rise in regional population density tied to intensified economic activity in that both local ( $q a^{\prime}$ sequence) and regional evidence indicate that climatic conditions during the interval accompanying the initial rise in stocking rates were, in fact, relatively moist. Locally, the end of Zone 6 ( 5650 to 4900 cal. BP) and Zone 5 ( 4900 to 4050 cal. BP) was associated with increased moisture levels and greater sediment stability as reflected in silt accumulations indicative of seasonal ponding events and the formation of incipient A soil horizons. The onset of moister conditions can also be traced in the rise of OC and MS values, a sharp increase in phytolith density, and the relatively low representation of Chenopodiaceae pollen, a common signature of aridity. From a regional perspective, the cyclical wet-dry cycles of the late-Holocene differ little from earlier cyclical intervals that occurred between 7000 and 11,000 years ago as evidenced locally in the $q a^{\prime}$ sequence and regionally by other data-sets. The high-resolution speleotherm sequence from Soreq Cave is especially revealing in tracing the wet-dry cycles of the Holocene between 4000 and 7000 years ago (Bar-Matthews and Ayalon, 2011). They note a sharp rise in moisture levels commencing $\sim 5600$ and peaking $~ 4700$ years ago. In his synthetic review, Issar (2003: 17) also describes the onset of wetter, cooler conditions after about 5000 years ago. Fluctuations in the Dead Sea levels also indicate a wet phase from $~ 5.6$ to $3.5 \mathrm{kyr}$ cal. BP (Migowski et al., 2006: 427), and 
geomorphic and palynological evidence from the Negev indicates rainfall was not only greater at this time but more evenly distributed seasonally (Rosen, 2007: 129-130).

\section{Anthropogenic forces: Emergent market economy and population growth}

If climatic deterioration was not the ultimate cause for desertification, what may have prompted the rise in stocking rates to levels that induced overgrazing? Here, we see anthropogenic forces as the ultimate driver that involved economic development and concomitant population growth and expansion. Relative to culturalhistoric context of the study area, the marked rise in stocking rates took place during the area's occupation by groups representing the Timnian, an agro-pastoral complex that extended across the southern Levant from some 7-8 kya to 4-5 kya (Henry, 1995: 359; Kozloff, 1981; Rosen, 2011a; Rothenberg and Glass, 1992; Rothenberg et al., 1979: 72; Rowan and Golden, 2009). In bridging the Chalcolithic and early Bronze periods, the complex was composed of semi-nomadic, pastoral groups that occupied desert settings extending from east central Sinai (Eddy and Wendorf, 1999; Kozloff, 1981; Rothenberg and Glass, 1992; Rothenberg et al., 1979) eastward through the Negev (Gilead, 1988; Rosen, 2011a) and into southern and southeastern Jordan (Abu-Azizeh, 2013; Henry, 1995). Beyond herding, Timnian groups hunted, especially gazelle, gathered wild plant foods, and cultivated cereal crops following a mobile settlement pattern in the vast stretches of arid lands that surrounded the emergent urban centers and copper mining districts situated in the Wadi Araba such as Tell el Magass, Hujayrat al-Ghuzlan, Timna, and Feinan (Faynan). The growth in population of these settled communities was tied to economic development involving the mining, production, and trade of copper and cortical flint flakes for the fabrication of tabular scrapers and the handling of ornaments of shell and stone and various other exotic items in an exchange system that stretched as far away as Egypt (Notroff et al., 2014; Schmidt and Khalil, 2009).

\section{Timnian settlement pattern and site structure}

Timnian groups followed a central-based wandering settlement pattern of transhumance in which their cyclical migrations appear to have been seasonally governed by the availability of water and pasturage (Abu-Azizeh, 2013; Henry, 1994, 1995). Dependent upon the differences in elevational amplitude of the landscape encompassed within their annual range, groups made either relative short, vertical or longer, horizontal 
transhumant migrations. During the winter wet season, groups aggregated into longterm encampments holding several nuclear families, and during the long, dry season, they dispersed and established ephemeral camps occupied by only one to two families. Studies of Timnian encampments reveal site structures that are linked to these seasonal shifts in mobility and group sizes associated with transhumance. The sites consist of stone-walled, curvilinear structures that often formed agglutinative, honeycomb layouts with pens or corrals tied to smaller installations presumably used as dwellings and storage facilities (Figure 9). Most sites are located in the open-air, but some occur within shallow rock shelters. Long-term sites display larger areas, deeper deposits, more complex site structures, more features, and higher artifact densities than those of their ephemeral counterparts (Abu-Azizeh, 2013; Henry, 1994, 1995).

\section{Population growth and site density}

A substantial growth in regional population is reflected in several survey-based, diachronic studies (Figure 1) that consistently reveal the Chalcolithic through early Bronze interval as a time of marked escalation in site and/or occupation densities (AbuAzizeh, 2013; Eddy and Wendorf, 1999; Henry, 2006: 92-93; Henry et al., 2001; Niemi and Smith, 1999; Rosen, 2011a: 7). The two archaeological surveys situated closest $(18-40 \mathrm{~km})$ to the study area encompassed some $46 \mathrm{~km} 2$ and identified 115 prehistoric sites, of which 25-50\% fell within the Chalcolithic-early Bronze interval (Henry, 2006: 92-93; Henry et al., 2001). Somewhat further away, a survey of the eastern flank of the southern Wadi Araba recorded over 300 sites, 91 of which were identified to period, and of these, some $38 \%$ contained Chalcolithic-early Bronze occupations (Henry et al., 2013; Niemi and Smith, 1999: 799-802). Similarly, Rosen's (2011a: 7) synthetic review and calculations of site densities reported by numerous surveys conducted in the central and southern portions of the Negev also show frequency peaks in the early Bronze, and Avner (2006: 53-55), while noting the continuous occupation of the region, found the Chalcolithic-early Bronze to be prominently represented in most of the surveys. In east central Sinai, the survey by Eddy and Wendorf (1999: 125, 134-135) identified some 77 prehistoric sites of which $75 \%$ contained Chalcolithic components. About $100 \mathrm{~km}$ east of the study area, in the al-Thulaythuwat area of southern Jordan, Abu-Azizeh (2013) found 171 potential nomadic camp sites within a survey of $435 \mathrm{~km} 2$, and close inspection of 94 of these revealed that $50 \%$ were affiliated with the Chalcolithic- early 
Bronze interval. Although site density only serves as a loose proxy in tracing prehistoric populations given the influences of geomorphic forces and settlement mobility levels, the consistent, widespread evidence of dramatic increases in site density during the Chalcolithic-early Bronze period strongly suggests a marked growth in population.

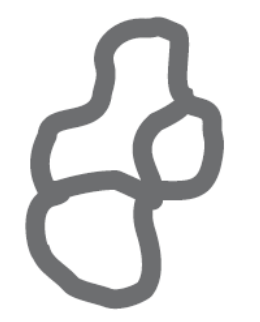

(a)

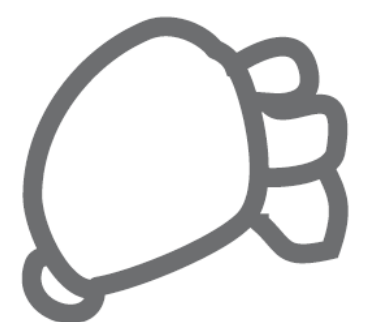

(b)

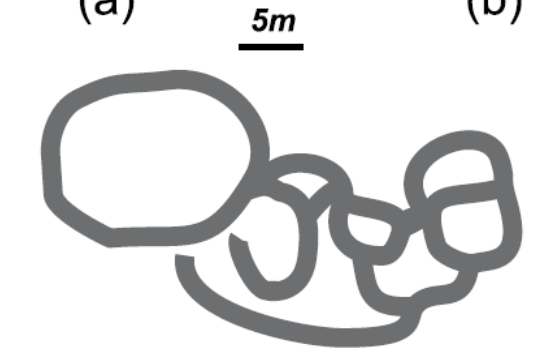

(c)

Figure 9. Site plans of selected Timnian sites redrawn after (a) Site Th 0.44 Unit A, Abu-Azizeh (2013); (b) Site S 48, Eddy and Wendorf (1999); and (c) Site Jebel el Jill, Henry (1995). Note that while the sizes and specific layouts of the architecture vary, most likely as an expression of group and herd sizes, all show a large enclosure (animal pen) accompanied by smaller installations thought to serve as dwelling and storage structures.

\section{Emergence of regional exchange and market economy}

Coincident with the rise in population, there is evidence for the emergence of a widespread trade network within the region that included materials such as copper, flint, ornamental items of shell and stone, and the secondary products derived from herding (Finkelstein and Silberman, 2001; Grigson, 1995; Klimscha, 2013a, 2013b; Notroff et al., 2014; Schmidt and Khalil, 2009, but cf. Sasson, 2008). And in this context, Timnian pastoral groups are thought to have served as the primary source of herding products and, in some areas, chert which was quarried from local outcrops to supply the lithic industry. In many ways, this notion echoes the suggestion of the transition from subsistence to market economies seen in the temporal-spatial distributions of livestock, but it also has indirect ramifications for understanding the ultimate cause of regional overgrazing. Given an emergent market for meat, milk products, and wool/goat hair, Timnian groups would have had the incentive to increase herd sizes beyond that 
associated with a subsistence economy and the normal carrying capacity allowed by pasturage, and, in turn, this would have initiated overgrazing.

\section{Chert quarries, tabular scrapers, and sheep shears}

A wide range of evidence indicates that embedded in their settlement patterns, Timnians quarried chert from local outcrops, sometimes at an industrial scale, for exchange within their immediate interaction spheres and beyond for the fabrication of tabular scrapers (Figure 10). Quarrying activities were most likely undertaken from winter wet-season encampments when groups had coalesced into larger, more permanent units often near chert outcrops (Quintero et al., 2002). The volumes of chert involved in this exchange network were astronomical. From their research in the Qa Jafr area, Quintero et al. (2002) estimate that over 0.25 million cores were contained in the surface finds of a single site spread over 12 ha, which in turn would have produced over 0.75 million cortical flakes, implying that cortical flakes numbering in the millions would have been produced from the sites in their study area alone. Similarly, Fujii (2003: 219) found several quarry areas in the Wadi Abu Tulayha along the western margin of Qa Jafr from which he estimated some 15,000 tabular scraper blanks were produced. Lithic assemblages from other sites, however, point to chert procurement and processing at a domestic scale that simply served the group in residence. Finds of bundles of tabular flakes and scrapers at small pastoral camps (Abu-Azizeh, 2013: 157; Fujii, 2011) and at trade centers such as Tell Hujayrat al- Ghuzlan (Khalil et al., 2003) suggest that they were held in sacks or bags for transport, perhaps even in standardized units. An intriguing implication of transporting the bulk loads of tabular flakes and scrapers is that donkeys were perhaps used to carry the cargo (Abu-Azizeh, 2013: 171; Klimscha, 2011: 286). Domestic donkey remains, in fact, have been identified at Tell Hujayrat alGhuzlan and donkeys appear as domestic stock in Egypt as early as 6 kya and as working stock by about 5.5 kya (Benecke, 2009; Blench, 2004; Epstein, 1971). Given the trade relationship with Egypt during the early Bronze, the adoption of donkeys as portage animals seems likely. The specific distribution pattern of tabular cores and scrapers appears to have been a combination of direct import from quarry areas to trade centers as well as downthe- line exchange between pastoral groups. The fabrication of 
tabular scrapers also apparently followed two lines of production, one involving craft specialists for the market economy and another related to production at the household level for domestic use.

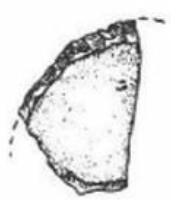

a

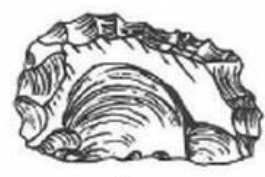

b

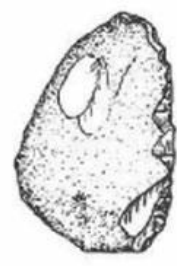

C

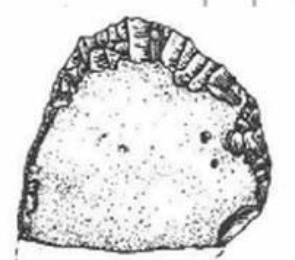

d
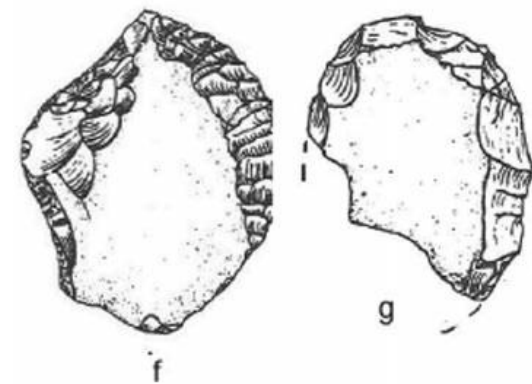

g

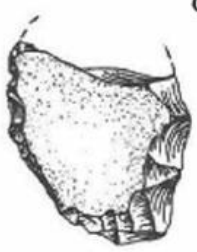

e

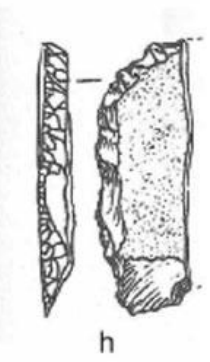

Figure 10. Illustration of tabular scrapers from the Timnian sites in the Wadi Hisma of southern Jordan (Henry, 1995). Note the convex, fan-shaped working edges and the rough-surfaced cortex on the faces of the tools.

The associations of chert quarry sites, lithic assemblages dominated by tabular coresflakes-scrapers, and sites with the distinctive, compound layout of Timnian encampments link the unique lithic industry to herding during late Chalcolithic-early Bronze times. What, however, may specifically explain this focus on the production of tabular scrapers, especially in such huge numbers? An explanation rests in their production and focal use for shearing sheep (Henry, 1995). In their 1914 survey of the Negev, Wooley and Lawrence (1915: 19-20) observed that oval 'scrapers' were used by shepherd-boys to shear their sheep. Inspired by this, Henry (1995: 372-373) undertook an actualistic experiment in shearing two Bedouin sheep using replicated tabular scrapers with remarkable success. A significant revelation of the experiment was in showing how the rough, abrasive surface of the cortical face of a tabular scraper, really a functional knife, allowed for griping the implement after it had been covered with slippery, yellow lanolin during shearing. This explains the unique feature of tabular 
scrapers in having been fabricated from cortical flakes. Additionally, the typical convex, fan-shaped, acute working edge of the implement facilitated the shearing process which involved cutting the tensed wool with a sweeping, rotary motion (Figure 10). A subsequent microscopic edge-wear study of seven replicated tabular scrapers used in sheep-shearing produced use-wear features attributed to soft material somewhat resembling that associated with the butchery of fresh meat (Barkett and Bell, 2011). This perhaps explains the interpretive results of earlier studies that viewed the scrapers as used in butchery (McConaughy, 1979), but as with most chipped stone tools, the scrapers may have served multiple functions. Use of tabular scrapers as sheep shears is consistent with the synchronous emergence of a market economy involving the secondary products of herding, an expansion of Timnian pastoral groups, and the presence of tabular scrapers as the hallmark artifact of the complex. And indirectly, these connections mesh with the corresponding escalation in stocking rates, overgrazing, and landscape transformation as traced in the Qa' Abū Nukhayla sediment column.

\section{Summary}

A multi-disciplinary investigation of a 5-m deep sediment column excavated in a dry lake bed near the 9.5 kya early Neolithic site of Ayn Abū Nukhayla revealed an early interval in which proxies of plant cover and stocking rates co-varied directly with climatic cycles. Beginning $~ 5.6 \mathrm{kcal} \mathrm{BP}$, however, this pattern changed with spherulite and phytolith densities failing to co-vary and with spherulites often greatly exceeding phytolith densities, which we suggest is indicative of overgrazing. Moreover, the lack of agreement between the high phytolith densities and other indicators of a desert landscape (i.e. geomorphic and palynologic) suggests that phytolith densities were inflated by fodder subsidies and as such are not entirely reflective of plant cover for this later interval. Given the co-incidental emergence of overgrazing with archaeological evidence for a marked rise in population, emergence of widespread trade, and expansion of the Timnian pastoral complex during Chalcolithic-early Bronze times, we argue that desertification was a consequence of socio-economic factors associated with a shift from a subsistence to a market economy (Figure 11). In addition, we contend that the signature lithic artifact variety (tabular scraper) that occurred in great abundance during this period was directly tied to the emergent market economy in having been used to 
shear sheep. Moreover, in that these changes took place largely concurrent with local and regionally recognized evidence of a moist interval, we conclude that the mid- to late-Holocene desertification of the southern Levant was induced more by anthropogenic than climatic factors.

Regional population rise perhaps induced by climatic amelioration
Market related incentive for raising stocking rates to levels exceeding pasturage that induced overgrazing and, in turn, desertification.
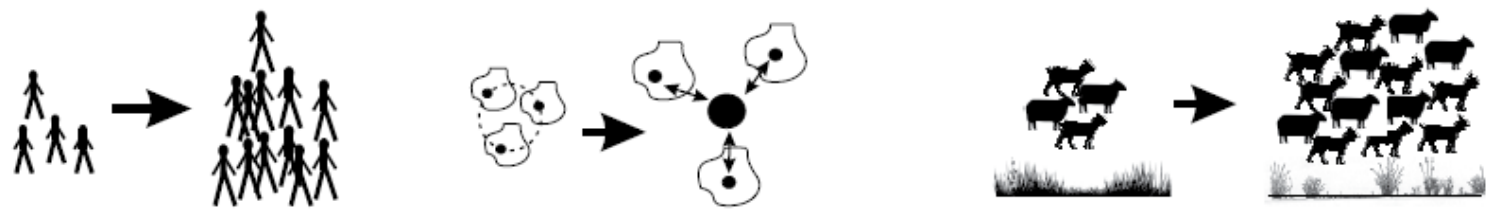

Figure 11. Schematic tracing the evolutionary factors leading to desertification as discussed in the text.

\section{Acknowledgements}

The assistance of representatives from the Department of Antiquities of Jordan and the American Center of Oriental Research in Amman/Boston greatly contributed to the success of the project. Also, we express our appreciation to Kim Ivey, Colleen Bell, and Veronica Mraz for editorial assistance on the manuscript.

\section{Funding}

The research was made possible by support from the National Science Foundation (Grants SBR-973148, SBR-0410097) and the Office of Research at the University of Tulsa. Marta Portillo's work is currently funded by the EU Horizon 2020 Marie

Sklodowska-Curie Actions (MICROARCHAEODUNG, H2020-MSCA-IF-2015702529).

\section{References}

Abu-Azizeh W (2013) The south-eastern Jordan's Chalcolithic- Early Bronze Age pastoral nomadic complex: Patterns of mobility and interaction. Paléorient 39(1): 149176.

Al Zaidaneen J (2007) Ain Abu Nukhayla Botanic Study (unpublished manuscript). 
Albert RM and Henry DO (2004) Herding and agricultural activities at the early Neolithic site of Ayn Abū Nukhayla (Wadi Rum, Jordan). The results of phytolith and spherulite analyses. Paléorient 30(2): 81-92.

Albert RM and Weiner S (2001) Study of phytoliths in prehistoric ash layers using a quantitative approach. In: Meunier JD and Colin F (eds) Phytoliths: Applications in Earth Sciences and Human History. Lisse: A.A. Balkema Publishers, pp. 251-266.

Albert RM, Bar-Yosef O, Goldberg P et al. (2003) Phytolith and mineralogical studies of hearths from the Middle Paleolithic levels of Hayonim cave (Galilee, Israel). Journal of Archaeological Science 30: 461-480.

Al-Jaloudy M (2001) Grassland and Pasture Crops, Country Pasture/ Forage Resource Profiles, Jordan. Available at:

http://www.fao.org/ag/AGP/AGPC/doc/Counprof/Jordan.htm.

Avner U (2006) Settlement patterns in the Wadi Arabah and the adjacent desert areas: A view from the Eilat region. In: Bienkowski $\mathrm{P}$ and Galor $\mathrm{K}$ (eds) Crossing the Rift: Resources, Routes, Settlement Patterns and Interaction in the Wadi Arabah. Oxford: Oxbow Books, pp. 51-74.

Avni Y, Porat N, Plakht J et al. (2006) Geomorphic changes leading to natural desertification versus anthropogenic land conservation in an arid environment, the Negev Highlands, Israel. Geomorphology 82(3-4): 177-200.

Babenko AN, Kisleva NK, Plakht I et al. (2007) Reconstruction of the Holocene vegetation in the Central Negev Desert, Israel, on the basis of palynological data on the Atzmaut zoogenic deposit. Russian Journal of Ecology 38(6): 417-426.

Baird D (2014) Origins of caprine herding. Proceedings of the National Academy of Sciences of the United States of America 111(24): 8702-8703.

Barker G, Gilbertson D and Mattingly D (2007) Archaeology and Desertification: Levant Supplementary Series, vol. 6. Oxford: Oxbow Books.

Barkett TA and Bell CA (2011) Tabular scrapers: Function revisited. Journal of Near Eastern Archaeology 74(1): 56-59.

Bar-Matthews M and Ayalon A (2011) Mid-Holocene climate variations revealed by high-resolution speleothem records from Soreq Cave, Israel and their correlation with cultural changes. The Holocene 21(1): 163-171.

Baruch U (1990) Palynological evidence of human impact on vegetation as recorded in Late-Holocene lake sediments in Israel. In: Bottema S, Entjes-Nieborg G and vanZeist

W (eds) Man's Role in the Shaping of Eastern Mediterranean Landscape. Rotterdam: A.A. Balkema Publishers, pp. 283-293.

Batello C (2011) Farming systems in arid rangelands of Syria and Jordan. Available at: http://www.fao.org/ag/agp/AGPC/DOC/PUBLICAT/field2/pub03Syria.htm.

Benecke N (2009) Faunal remains of Tall Hujayrat al-Ghuzlan (Excavations 20002004). In: Khalil L and Schmidt K (eds) Prehistoric Aqaba I. Rahden: Marie Leidorf, pp. 339-354.

Blench R (1999) Rangeland degradation and socio-economic changes among the Bedu of Jordan; results of the 1995 IFAD Survey. In: Squires VR and Sidahmed AE (eds) Drylands: Sustainable Use of Rangelands in the Twenty-First Century. Rome: IFAD, pp. $397-423$. 
Blench R (2004) The history and spread of donkeys in Africa. In: Fielding D and Starkey P (eds) Donkeys, People and Development. Brussels: ATHESA, CTA, pp. 2230.

Brochier JE, Villa P, Giacomarra M et al. (1992) Shepherds and sediments: Geoethnoarchaeology of pastoral sites. Journal of Anthropological Archaeology 11: 47102.

Byrd BF (2005) Reassessing the emergence of village life in the Near East. Journal of Archaeological Research 13: 231-290.

Canti MG (1997) An investigation of microscopic calcareous spherulites from herbivore dungs. Journal of Archaeological Science 24: 219-231.

Canti MG (1998) The micromorphological identification of faecal spherulites from archaeological and modern materials. Journal of Archaeological Science 25: 435-444.

Canti MG (1999) The production and preservation of faecal spherulites: Animals, environment and taphonomy. Journal of Archaeological Science 26: 251-258.

Cordova CE (2007) Millennial Landscape Change in Jordan: Geoarchaeology and Cultural Ecology. Tucson, AZ: University of Arizona Press.

Cordova CE, Kalchgruber R and Winsborough B (2014) Geology, landforms, and depositional systems in Wadi Rum. In: Henry DO and Beaver JE (eds) The Sands of Time: The Desert Neolithic Settlement of Ayn Abū Nukhayla. Berlin: ex oriente, pp. 1328.

Dean RE (2014) Hunting and herding at Ayn Abū Nukhayla: The vertebrate faunal assemblage. In: Henry DO and Beaver JE (eds) The Sands of Time: The Desert Neolithic Settlement of Ayn Abū Nukhayla. Berlin: ex oriente, pp. 69-90.

Eddy F and Wendorf F (1999) An Archaeological Investigation of the Central Sinai, Egypt. Boulder, CO: University of Colorado Press.

Emery-Barbier A (2014) Establishing the environment, seasonality and economy through plant micro-remains: Pollen and starch. In: Henry DO and Beaver JE (eds) The Sands of Time: The Desert Neolithic Settlement of Ayn Abū Nukhayla. Berlin: ex oriente, pp. 105-120.

Epstein H (1971) The Origin of the Domestic Animals of Africa, vol. II. New York: Africana Publishing Co. Falconer SE and Fall PL (1995) Human impacts on the environment during the rise and collapse of civilization in the eastern

Mediterranean. In: Steadman DW and Mead JI (eds) Late Quaternary Environments and Deep History: A Tribute to Paul S. Martin, vol. 3. Hot Springs, SD: The Mammoth Site of Hot Springs, Scientific Papers, pp. 84-101.

Finkelstein I and Silberman NA (2001) The Bible Unearthed: Archaeology's New Vision of Ancient Israel and the Origin of Its Sacred Texts. New York: Free Press.

Fujii S (2003) Qa' Abu Tulayha West, 2002 an interim report of the 6th and final season. Annual of the Department of Antiquities of Jordan 47: 195-223.

Fujii S (2010) Domestication of runoff surface water: Current evidence and new perspectives from the Jafr pastoral Neolithic. In: Rollefson GO and Gebel HGK (eds) Neo-Lithics 2/10 the Newsletter of Southwest Asian Neolithic Research: Special Topic on the Domestication of Water. Berlin: ex oriente, pp. 14-32. 
Fujii S (2011) 'Lost Property' at Wadi Qusayr 173: Evidence for the transportation of tabular scrapers in the Jafr Basin, Southern Jordan. Levant 43(1): 1-14.

Garrard A, Colledge S and Martin L (1996) The emergence of crop cultivation and caprine herding in the 'marginal zone' of the southern Levant. In: Harris D (ed.) The Original and Spread of Agriculture and Pastoralism in Eurasia. Washington, DC: Smithsonian Press, pp. 204-226.

Geist HJ and Lambin EF (2004) Dynamic causal patterns of desertification. BioScience 54(9): 817.

Gilead I (1988) The Chalcolithic Period in the Levant. Journal of World Prehistory 3: 396-443.

Goring-Morris N and Belfer-Cohen A (2011) Neolithization processes in the Levant: The outer envelope. Current Anthropology 52(4): 195-208.

Grigson C (1995) Plough and pasture in the early economy of the southern Levant. In: Levy TE (ed.) The Archaeology of Society in the Holy Land. London: Leicester University Press, pp. 245-268.

Henry DO (1994) Prehistoric cultural ecology in southern Jordan. Science 265: 336341.

Henry DO (1995) The Timnian and pastoral nomadism in the Chalcolithic. In: Henry DO (ed.) Prehistoric Cultural Ecology and Evolution: Insights from Southern Jordan. New York: Plenum Press, pp. 353-374.

Henry DO (2006) Cultural and geological influences on prehistoric site distributions in the Wadi Arabah. In: Bienkowski P and Galor K(eds) Crossing the Rift: Resources, Routes, Settlement Patterns and Interaction in the Wadi Arabah. Oxford: Oxbow Books, pp. 91-102.

Henry DO (2014a) Pulling it all together, answers to many questions. In: Henry DO and Beaver JE (eds) The Sands of Time: The Desert Neolithic Settlement of Ayn Abū Nukhayla. Berlin: ex oriente, pp. 315-346.

Henry DO (2014b) The problems, questions and getting the answers. In: Henry DO and Beaver JE (eds) The Sands of Time: The Desert Neolithic Settlement of Ayn Abu Nukhayla. Berlin: ex oriente, pp. 1-13.

Henry DO and Beaver JE (eds) (2014a) The Sands of Time: The Desert Neolithic Settlement of Ayn Abū Nukhayla. Berlin: ex oriente.

Henry DO and Beaver JE (2014b) The stratigraphy, occupational phases and chronometry. In: Henry DO and Beaver JE (eds) The Sands of Time: The Desert Neolithic Settlement of Ayn Abü Nukhayla. Berlin: ex oriente, pp. 41-48.

Henry DO and Nowell A (2007) Time-space patterns observed in Pre-Pottery Neolithic B point attributes from Ayn Abū Nukhayla. Journal of Eurasian Prehistory 5(1): 3-20.

Henry DO, Cochrane M, Burns C et al. (2013) Analysis and interpretation of lithic assemblages recovered from sites in the Southeast Araba Archaeological Survey. In: Parker S and Smith A (eds) The Roman Aqaba Report, vol. I. Boston, MA: ASOR Excavation Reports, pp. 1-15.

Henry DO, Kadowaki S and Bergin S (2014) Reconstructing Early Neolithic social and economic organization through spatial analysis at Ayn Abū Nukhayla, southern Jordan. American Antiquity 79(3): 401-424. 
Henry DO, Kerry K, Brauer H et al. (2001) Survey of prehistoric sites, Wadi Araba, southern Jordan. Bulletin American Schools of Oriental Research 323: 1-19.

Hill JB (2006) Human Ecology in the Wadi al-Hasa Land Use and Abandonment through the Holocene. Tucson, AZ: University of Arizona Press.

Issar AS (2003) Climate Changes during the Holocene and their Impact on Hydrological Systems. Cambridge: Cambridge University Press.

Khalil L, Eichmann R and Schmidt K (2003) Archaeological survey and excavations at the Wadi Al-Yutum and Al-Magass Area - Al-'Aqaba (ASEYM): A preliminary report on the third and fourth seasons excavations at Tall Hujayrat Al-Ghuzlan in 2002 and 2003, Wadi Al-Yutum. Annual of the Department of Antiquities of Jordan 47: 159-182.

Klimscha F (2011) Long-range contacts in the Late Chalcolithic of the southern Levant. Excavations at Tall Hujayrat al-Ghuzlan and Tall al-Magass near Aqaba, Jordan. In: Mynařova J (ed.) Long-Range Contacts in the Late Chalcolithic of the Southern

Levant. Excavations at Tall Hujayrat al-Ghuzlan and Tall al-Magass near Aqaba, Jordan. Praha: Charles University, pp. 177-210.

Klimscha F (2013a) Another great transformation. Zeitschrift für Orient Archäologie 6, 2013(2014), 82-112.

Klimscha F (2013b) Innovations in Chalcolithic metallurgy in the Southern Levant during the 5th and 4th Millennium BC. Copper-production at Tall Hujayrat al-Ghuzlan and Tall al- Magass, Aqaba Area, Jordan. In: Burmeister S, Hansen S, Kunst M et al. (eds) Metal Matters: Innovative Technologies and Social Change in Prehistory and Antiquity. Rahden: Marie Leidorf, pp. 1-64.

Koch J, Schaldach R and Kolking C (2009) Modeling the impact of rangeland management strategies on (semi-)natural vegetation in Jordan. In: 18th World IMACS / MODSIM Congress, Cairns, QLD, Australia, 13-17 July 2009.

Kochy M, Mathaj M, Jeltsch F et al. (2008) Resilience of stocking capacity to changing climate in arid to Mediterranean landscapes. Regional Environmental Change 8: 73-87.

Kohler-Rollefson I (1988) The aftermath of the Levantine Neolithic Revolution in the light of ecological and ethnographic evidence. Paléorient 14: 87-93.

Kozloff B (1981) Pastoral nomadism in Sinai: An ethno-archaeological study. Production pastorales et societe: bulletin d'ecologie et d'anthropologie des societies pastorales 8: 19-24.

Kuijt I (2000) Life in Neolithic farming communities: An introduction. In: Kuijt I (ed.) In Life in Neolithic Farming Communities. New York: Kluwer Academic/Plenum, pp. 3-13.

Kuijt I and Bar-Yosef O (1994) Radiocarbon chronology for the Levantine Neolithic: Observations and data. In: Bar-Yosef O and Kra RS (eds) Late Quaternary Chronology and Paleoclimates of the Eastern Mediterranean. Tucson, AZ: Radiocarbon, pp. 227246.

Kuijt I and Goring-Morris N (2002) Foraging, farming, and social complexity in the Pre-Pottery Neolithic of the Southern Levant: A review and synthesis. Journal of World Prehistory 16(4): 361-440.

Lancaster W and Lancaster F (1991) Limitations on sheep and goat herding in the Eastern Badia of Jordan: An ethno-archaeological enquiry. Levant XXIII: 125-138. 
Langgut D, Neumann FH, Stein M et al. (2014) Dead Sea pollen record and history of human activity in the Judean Highlands (Israel) from the Intermediate Bronze into the Iron Ages ( 2500-500 BCE). Palynology 38(2): 280-302.

McConaughy MA (1979) Formal and functional analysis of chipped stone tools from Bab edh-Dhra. Unpublished Doctoral Dissertation, University of Pittsburgh.

McCorriston J and Hayes E (2014) Archaeobotanical finds from Ayn Abū Nukhayla. In: Henry DO and Beaver JE (eds) The Sands of Time: The Desert Neolithic Settlement of Ayn Abū Nukhayla. Berlin: ex oriente, pp. 139-144.

Migowski C, Stein M, Prasad S et al. (2006) Holocene climate variability and cultural evolution in the Near East from the Dead Sea sedimentary record. Quaternary Research 66(3): 421-431.

Niemi TM and Smith AM (1999) Initial results of the Southeastern Wadi Araba, Jordan geoarchaeological study: Implications for shifts in Late Quaternary aridity. Geoarchaeology 14(8): 791-820.

Notroff J, Schmidt K, Siegel U et al. (2014) Reconstructing networks, linking spaces the view from the Aqaba region (Jordan). Levant 46(2): 249-267.

Portillo M and Albert RM (2014) Early crop cultivation and caprine herding: The evidence from phytolith and fecal spherulite studies. In: Henry DO and Beaver JE (eds) The Sands of Time: The Desert Neolithic Settlement of Ayn Abū Nukhayla. Berlin: ex oriente, pp. 121-137.

Portillo M, Albert RM and Henry DO (2009) Domestic activities and spatial distribution in Ain Abū Nukhayla (Wadi Rum, Southern Jordan): The use of phytoliths and spherulites studies.Quaternary International 193: 174-183.

Quintero L, Wilke PL and Rollefson GO (2002) From flint mine to fan scraper: The late prehistoric Jafr industrial complex. Bulletin of American Schools of Oriental Research 327: 17-48.

Reynolds JF, Stafford-Smith DM and Lambin E (2003) Do humans cause deserts? An old problem through the lens of a new framework: The Dahlem Desertification Paradigm. In: VIIth International Rangelands Congress, Durban, 26 July-1 August, pp. 2042-2048.

Rosen AM (2007) Civilizing Climate: Social Responses to Climate Change in the Ancient Near East. Lanham, MD: Alta Mira Press.

Rosen SA (2011a) Desert chronologies and periodization systems. In: Lovell JL and Rowan YM (eds) Culture, Chronology and Theory. Oxford: Oxbow Books, pp. 71-83.

Rosen SA (2011b) The desert and the pastoralist: An archaeological perspective on human-landscape interaction in the Negev over the millennia. Annals of Arid Zone 50(3-4): 1-15.

Rothenberg B and Glass J (1992) The beginnings and the development of early metallurgy and the settlement and chronology of the Western Arabah, from the Chalcolithic Period to Early Bronze Age IV. Levant 24: 141-157.

Rothenberg B, Danin A, Garfunkel Z et al. (1979) Sinai: Pharoahs, Miners, Pilgrims and Soldiers. Washington, DC; New York: Joseph J. Binns Publisher. Rowan Y and Golden J (2009) The Chalcolithic period of the Southern Levant: A synthetic review. Journal of World Prehistory 22: 1-92. 
Sasson A (2008) Animal Husbandry in Ancient Israel: A Zooarchaeological Perspective on Livestock Exploitation, Herd Management and Economic Strategies. London: Equinox. Schmidt K and Khalil L (eds) (2009) Prehistoric Aqaba I. Orient Archäologie, vol. 23. Rahden: Marie Leidorf.

Shahack-Gross R, Marshall F and Weiner S (2003) Geo-ethnoarchaeology of pastoral sites: The identification of livestock enclosures in abandoned Maasai settlements. Journal of Archaeological Science 30: 439-459.

Simmons AH (2000) Villages on the edge: Regional settlement change and the end of the Levantine Pre-Pottery Neolithic. In: Kuijt I (ed.) Life in Neolithic Farming Communities. New York: Kluwer Academic, pp. 211-230.

Simmons AH (2007) The Neolithic Revolution in the Near East: Transforming the Human Landscape. Tucson, AZ: University of Arizona Press.

Simms SR (1988) The archaeological structure of a Bedouin camp. Journal of Archaeological Science 15: 197-211.

Simms SR and Russell KW (1997) Tur Imdai Rockshelter: Archaeology of recent pastoralists in Jordan. Journal of Field Archaeology 24: 459-472.

Stiner MC, Buitenhuis H, Duru G et al. (2014) A forager-herder trade-off, from broadspectrum hunting to sheep management at Aşılı Hoyuk, Turkey. Proceedings of the National Academy of Sciences of the United States of America 111(23): 8404-8409.

Tchernov E and Horwitz LK (1990) Herd management in the past and its impact on the landscape of the southern Levant. In: Bottema S, Entjes-Nieborg G and vanZeist W (eds) Man's Role in the Shaping of Eastern Mediterranean Landscape. Rotterdam: A.A. Balkema Publishers, pp. 207-218.

Tsartsidou G, Lev-Yadun S, Albert RM et al. (2007) The phytolith archaeological record: Strengths and weaknesses based on a quantitative modern reference collection from Greece. Journal of Archaeological Science 34: 1262-1275.

Weninger B, Joris O and Danzeglocke U (2007) Cologne radiocarbon calibration and paleoclimate research package. Available at: http://www.calpal.de.

Whiteford W (2002) The Ecology of Desert Systems. London: Academic Press.

Woolley CL and Lawrence TE (1915) Wilderness of Zin Annual of the Palestine Exploration Fund, 1914-1915.London: Harrison \& Sons.

Zohary M (1973) Geobotanical Foundations of the Middle East, 2 vols. Stuttgart: Fischer. 